\title{
CDH1 and SNAI1 are regulated by E7 from human papillomavirus types 16 and 18
}

\author{
PEDRO ROSENDO-CHALMA ${ }^{1,2}$, VERÓNICA ANTONIO-VEJAR ${ }^{2,3}$, GABRIELE DAVIDE BIGONI-ORDÓÑEZ ${ }^{2}$, \\ CARLOS CÉSAR PATIÑO-MORALES ${ }^{2}$, AMPARO CANO-GARCÍA ${ }^{4,5}$ and ALEJANDRO GARCÍA-CARRANCÁ ${ }^{2}$
}

\author{
${ }^{1}$ Programa de Doctorado en Ciencias Biomédicas, Instituto de Investigaciones Biomédicas (IIB), \\ Universidad Nacional Autónoma de México (UNAM), Mexico City 10450; ${ }^{2}$ Laboratorio de Virus y Cáncer, Unidad de \\ Investigación Biomédica en Cáncer of Instituto de Investigaciones Biomédicas-Universidad Nacional Autónoma de México \\ (IIB-UNAM) and División de Investigación Básica of Instituto Nacional de Cancerología-Secretaría de Salud (INCan-SSA), \\ Mexico City 14080; ${ }^{3}$ Laboratorio de Biomedicina Molecular, Unidad Académica de Ciencias Químico Biológicas \\ (UACQB), Universidad Autónoma de Guerrero (UAGro), Chilpancingo, Guerrero 39090, Mexico; \\ ${ }^{4}$ Departamento de Bioquímica, Universidad Autónoma de Madrid (UAM), Instituto de Investigaciones Biomédicas \\ ‘Alberto Sols' (CSIC-UAM), Instituto de Investigación Sanitaria del Hospital Universitario La Paz (IdiPAZ); \\ ${ }^{5}$ Centro de Investigación Biomédica en Red de Cáncer (CIBERONC), Madrid 28029, Spain
}

Received January 11, 2019; Accepted October 24, 2019

DOI: $10.3892 /$ ijo.2020.5039

\begin{abstract}
A common characteristic of cancer types associated with viruses is the dysregulated expression of the $\mathrm{CDHI}$ gene, which encodes E-cadherin, in general by activation of DNA methyltransferases (Dnmts). In cervical cancer, E7 protein from high risk human papillomaviruses (HPVs) has been demonstrated to interact with Dnmt1 and histone deacetylase type 1 (HDAC1). The present study proposed that E7 may regulate the expression of $\mathrm{CDHl}$ through two pathways: i) Epigenetic, including DNA methylation; and ii) Epigenetic-independent, including the induction of negative regulators of $\mathrm{CDHl}$ expression, such as Snail family transcriptional repressor Snail and Snai2. To test this hypothesis, HPV16- and HPV18-positive cell lines were used to determine the methylation pattern of the $\mathrm{CDH} 1$ promoter and its expression in association with its negative regulators. Different methylation frequencies were identified in the $\mathrm{CDH1}$ promoter in $\mathrm{HeLa}(88.24 \%)$ compared with $\mathrm{SiHa}(17.65 \%)$ and $\mathrm{Ca} \mathrm{Ski}$ $(0 \%)$ cell lines. Significant differences in the expression of SNAII were observed between these cell lines, and an inverse association was identified between the expression levels of SNAII and CDH1. In addition, suppressing E7 not only increased the expression of $C D H 1$, but notably decreased the
\end{abstract}

Correspondence to: Dr Alejandro García-Carrancá, Virus and Cancer Laboratory, Biomedical Research Unit on Cancer, National Cancer Institute, Ministry of Health, 22 San Fernando Avenue, Section XVI, Tlalpan, Mexico City 14080, Mexico

E-mail: carranca@biomedicas.unam.mx

Key words: epigenetic, human papillomavirus, E7, SNAI1, SNAIL/SNAIL1, SNAI2, SLUG/SNAIL2, CDH1, E-cadherin expression of SNAII and modified the methylation pattern of the $\mathrm{CDH1}$ promoter. These results suggested that the expression of $\mathrm{CDH} 1$ was dependent on the expression of SNAII and was inversely associated with the expression of E7. The present results indicated that E7 from HPV16/18 regulated the expression of $\mathrm{CDH} 1$ by the two following pathways in which Snai1 is involved: i) Hypermethylation of the $\mathrm{CDHl}$ promoter region and increasing expression of $S N A I 1$, as observed in HeLa; and ii) Hypomethylation of the $\mathrm{CDH} 1$ promoter region and expression of SNAII, as observed in SiHa. Therefore, the suppression of $C D H 1$ and expression of SNAII may be considered to be biomarkers of metastasis in uterine cervical cancer.

\section{Introduction}

According to current research, 15-20\% of all cases of cancer can be attributed to infectious agents, including Helicobacter pylori and human papillomavirus (HPV), followed by hepatitis B virus (HBV), hepatitis C virus (HCV) and the Epstein-Barr virus (EBV) (1-3). In HPV, specifically types 16, 18, $31,33,35,39,45,51,52,56,58$ and 59 that are commonly referred to as high-risk (HR), are not only associated with cervical cancer (CC), the third most prevalent type of cancer worldwide in women in 2017, but also with other tumor types, including anal, penile, vulvar, vaginal and head and neck cancer $(1,4)$.

Persistent infections with HR-HPVs are necessary, but not sufficient to cause cancer, indicating the existence of multistep actions in viral carcinogenesis that contribute to the characteristic hallmarks underlying the phenotype of tumors $(3,5)$. Thus, it has been of great interest to study mechanisms by which persistent infections with these viruses contribute to cancer development. HPV has been demonstrated to induce a series of mechanisms that contribute to the evasion of the immune response and apoptosis-activated cell death, and finally the transformation, proliferation and cellular immortalization of the host cell $(6,7)$. 
HPV life cycle disruption due to integration of the viral genome into the cellular genome $(8,9)$ and activation of the cell methylation machinery have been demonstrated to be involved in the carcinogenic process of CC among other factors (10-12). Specifically, the HR-HPV E7 oncoprotein has been reported to serve a crucial role in oncogenic transformation due to its ability to form complexes with members of the retinoblastoma protein (pRB) family and destabilize them $(13,14)$, in addition to the ability to interact with other proteins, including histone deacetylase 1 (HDAC1) (15) and DNA methyltransferase 1 (Dnmt1) (16).

E7 binds to HDAC1 via its zinc finger-like motif through an intermediary protein Mi2 $\beta$, which is a component of the nucleosome remodeling and histone deacetylation (NURD) complex that has the ability to modify chromatin structure trough both deacetylation of histones and ATP-dependent nucleosome repositioning $(17,18)$. The formation of this complex is necessary for the maintenance of viral episomes, controlling cell proliferation and extending cell life $(15,17)$. Consistent with this, a chromatin immunoprecipitation assay in Ca Ski cells demonstrated that E7 and HDACs are associated with the major histocompatibility complex (MHC) class I promoter and histone deacetylation (19), as well as chromatin repression and the downregulation of $M H C$ class I genes and MHC class I heavy chain, and repression of the genes encoding the transporter associated with antigen processing subunit 1 (TAP1) and low molecular weight protein 2 (LMP2) (20). Furthermore, an association with Dnmt1 is directed and mediated by the conserved region 3 (CR3) zinc-finger region of E7, which is known to contribute to E7 transformation functions and stimulate the methyltransferase activity of Dnmt1, which may lead to aberrant genome methylation and cellular transformation as a consequence of the silencing of tumor-suppressor genes (16). Another study has demonstrated that in samples of normal cervix and cervical cancer, HPV types 16 and 18 activate the cell methylation machinery to methylate viral DNA, as well as the promoter regions of cellular genes, including cyclin A1, Rubicon-like autophagy enhancer, retinoic acid receptor $\beta 2$, cadherin $1(C D H 1)$, death-associated protein kinase 1 , human telomerase reverse transcriptase 1 (hTERT1), hTERT2, hypermethylated in cancer 1 and Twist Family BHLH Transcription Factor 1 (21). Therefore, previous evidence suggests that HR-HPV E7 serves an important role in the activation of the cellular methylation machinery, which regulates the transcription of viral and cellular genes either during their productive infection during its life cycle or during the carcinogenic process.

The mechanisms by which E7 is involved in the regulation of gene expression at the chromatin level are not well understood. It has been observed that a common characteristic of several cancer types associated with viruses is the decreased expression of $C D H 1$, which encodes E-cadherin, through epigenetic mechanisms (22-24). In the case of cancer types associated with HPV infections, it has been demonstrated that HPV16 E7 suppresses the transcription of $C D H 1$, which reduces protein expression of E-cadherin $(25,26)$. In addition, HPV16 E7 has been reported to increase the amount and activity of Dnmt1 in NIKS cells, which are derived from foreskin keratinocytes transfected with HPV16 E7 or NIKS bearing episomal HPV16 DNA (26); however, NIKS cells not infected with HPV16 and NIKS bearing episomal HPV16 DNA did not exhibit any differences in the $\mathrm{CpG}$ methylation status of the $\mathrm{CDHI}$ promoter regions, as all $\mathrm{CpG}$ sites were unmethylated (26). It is evident that HPV activates the methylation machinery via E7/Dnmt1; however, it is not clear how HPV induces $C D H 1$ repression by epigenetic mechanisms.

Since HR-HPVs E7 has been demonstrated to interact with Dnmt1 and HDAC1, the aim of the current study was to determine the methylation pattern of the $\mathrm{CDH} 1$ promoter region in $\mathrm{HeLa}$, SiHa and Ca Ski cell lines positive for HPV16 and HPV18. Additionally, associations with transcription factors Snai1 and Snai2, which are negative regulators of $\mathrm{CDH} 1$ expression and inducers of the epithelial-mesenchymal transition (EMT) process (27), were evaluated. $\mathrm{HeLa}, \mathrm{SiHa}$ and Ca Ski cell lines were selected for the present study, as they are representative of the most frequent cancer types of the uterine cervix with positive HR-HPV infection with different viral loads and epithelial origins, including cervical adenocarcinoma, cervical squamous cell carcinoma and cervical epidermoid carcinoma (28-34).

\section{Materials and methods}

Cell lines. As reported by the American type culture collection, HeLa cells are derived from a female African-American patient with uterine cervical adenocarcinoma and are reported to contain 10-50 integrated copies of HPV18 per cell (30-36). SiHa cells are derived from a female Asian patient with grade II cervical squamous cell carcinoma and are reported to contain 1-2 integrated copies of HPV16 per cell $(29,30,33,36)$. Ca Ski cells are derived from a female Caucasian patient with cervical epidermoid carcinoma and are reported to contain 500-600 integrated copies of HPV16 per cell $(28,30,36)$. HaCaT is a non-tumorigenic immortalized human epidermal cell line derived from skin keratinocytes. All cell lines were authenticated through STR DNA profiling (ID no. DP0297) by the University of Colorado DNA Sequencing \& Analysis Core. $\mathrm{HeLa}, \mathrm{SiHa}$ and $\mathrm{HaCaT}$ cell lines (ATCC) were cultured in DMEM (cat. no. 12800-058; Gibco; Thermo Fisher Scientific, Inc.); Ca Ski cells were cultured in RPMI medium (cat. no. 31800-014; Gibco; Thermo Fisher Scientific, Inc.). All cell lines were supplemented with $10 \%$ fetal bovine serum (FBS; cat. no. 16000-044; Gibco; Thermo Fisher Scientific, Inc.) and 1X penicillin-streptomycin (cat. no. 15140122; Gibco; Thermo Fisher Scientific, Inc.) and were incubated in a humidified chamber at $37^{\circ} \mathrm{C}$ with $5 \% \mathrm{CO}_{2}$.

Untransfected MCF-7 cells and MCF-7 cell stable clones transfected with a pcDNA 3.1 expression vector (Invitrogen; Thermo Fisher Scientific, Inc) with the bicistronic E6/E7 region from HPV18 (MCF-7 pE6/E7) were kindly provided by Dr Erick de la Cruz Hernández (Juarez Autonomous University of Tabasco, Villahermosa, Mexico) and were cultured with $800 \mu \mathrm{g} / \mathrm{ml}$ Geneticin in DMEM/F12 for 3 weeks as previously described (37-39). Untransfected C33-A cells and C33-A cell stable clones transfected with a pcDNAE7 plasmid (C33-A pE7/HPV16) were kindly provided by Dr Patricio Gariglio (CINVESTAV-IPN, Mexico City, Mexico) and were cultured with $800 \mu \mathrm{g} / \mathrm{ml}$ Geneticin in DMEM for 2 weeks as previously described (40). 
Treatments with 5-aza-2'-deoxycytidine (5-AzadC) and trichostatin A (TSA). 5-AzadC causes DNA demethylation or hemi-demethylation that results in gene activation by inhibiting Dnmt activity (41). TSA has been used as a histone deacetylase inhibitor, which causes histone hyperacetylation that leads to chromatin relaxation and modulation of gene expression (42). 5-AzadC and TSA were obtained from Sigma-Aldrich; Merck KGaA (cat. nos. A3656 and T8552, respectively) and resuspended in DMSO (Sigma-Aldrich; Merck KGaA; cat. no. D8418) to obtain working stock solutions (10.0 mM 5-AzadC and $1.0 \mathrm{mM}$ TSA). The 5-AzadC and TSA stock solutions were aliquoted, protected from light and stored at $-80^{\circ} \mathrm{C}$ for later use. A total of $4.5 \times 10^{5} \mathrm{HeLa}$ and $5 \times 10^{5} \mathrm{SiHa}$ cells were seeded in p60 boxes in triplicate and were treated with 5 and $10 \mu \mathrm{M} 5$-AzadC and 200 and $500 \mathrm{nM}$ TSA. Untreated cells or cells treated with DMSO were used as controls. The total volume of culture medium was $3 \mathrm{ml}$, which was supplemented with $10 \%$ FBS and did not contain any antibiotics. Assays were performed protected from light and the cells were incubated for $48 \mathrm{~h}$ at $37^{\circ} \mathrm{C}$ with $5 \% \mathrm{CO}_{2}$. The culture medium was replaced after $24 \mathrm{~h}$ due to the half-life of 5-AzadC and TSA.

Transfection with short interfering RNA (siRNA). siRNAs targeting HPV16 and HPV18 E7 were designed as previously described $(43,44)$ and obtained from Ambion (Thermo Fisher Scientific, Inc.; cat. nos. s237642 and s237640). Silencer ${ }^{\circledR}$ Select GAPDH siRNA (Hs, Mm, Rn) (cat. no. 4390849; Ambion; Thermo Fisher Scientific, Inc.) was used as a positive transfection control to select the transfection agent (Lipofectamine ${ }^{\circledR}$ 2000 or siPORT ${ }^{\mathrm{TM}} \mathrm{NeoFX}^{\mathrm{TM}}$ ) and to optimize gene silencing without affecting cell viability according to the manufacturer's protocol and as previously described (45-50). siRNAs were resuspended in UltraPure ${ }^{\mathrm{TM}}$ DNase/RNase-free distilled water (cat. no. 10977-015; Thermo Fisher Scientific, Inc.) to obtain a working stock of $10 \mu \mathrm{M}$. siRNAs were then aliquoted and stored at $-80^{\circ} \mathrm{C}$ for later use.

Transfection with siRNA was performed in triplicate using the siPORT ${ }^{\mathrm{TM}} \mathrm{NeoFX}^{\mathrm{TM}}$ kit (cat. no. AM4511; Ambion; Thermo Fisher Scientific, Inc.) according to the manufacturer's protocol. A total of $7.5 \times 10^{4} \mathrm{HeLa}$ and $8.0 \times 10^{4} \mathrm{SiHa}$ cells/well were seeded in a 12-well plate. HeLa cells were transfected with $30 \mathrm{nM}$ siRNA against HPV18 E7, whereas SiHa cells were transfected with $30 \mathrm{nM}$ siRNA against HPV16 E7. In addition, $30 \mathrm{nM}$ siRNA targeting $G A P D H$ was transfected as a positive control in both cell lines. Cells subjected to treatment with siPORT ${ }^{\mathrm{TM}} \mathrm{NeoFX}^{\mathrm{TM}}$ Transfection Agent with Opti-MEM ${ }^{\circledR}$ I (cat. no. 31985070; Thermo Fisher Scientific, Inc.) were used as a reference control to obtain the relative values, and untransfected cells were used as a reference control for statistical comparisons. Culture medium supplemented with $12 \%$ FBS and no antibiotics was added to make up a final transfection volume of $1.2 \mathrm{ml}$. Cells were incubated for $48 \mathrm{~h}$ at $37^{\circ} \mathrm{C}$ with $5 \% \mathrm{CO}_{2}$ and subsequently the extraction of nucleic acids and proteins was performed. Transfection efficiency was determined by measuring the expression of E7 and GAPDH at the mRNA level.

Bisulfite conversion and DNA methylation analysis. Total genomic DNA was isolated from the treated and transfected cell lines using the Wizard ${ }^{\circledR}$ Genomic DNA Purification kit (cat. no. A1120; Promega Corporation) and $1.5 \mu \mathrm{g}$ genomic DNA was treated with bisulfite according to the manufacturer's protocol of the EZ DNA Methylation-Gold ${ }^{\mathrm{TM}}$ kit (cat. no. D5006; Zymo Research Corp.). Methylation of CpG sites at the $C D H 1$ promoter region was analyzed by the bisulfite sequencing PCR (BSP) protocol (Fig. 1A) (10-12,51,52) or using oligonucleotides for MSP-protocol provided by Dr Alfonso Dueñas-Gonzalez (INCan-UNAM, Mexico City, Mexico); the PCR conditions for MSP-protocol were the same as those used for the BSP protocol. PCR was performed with a total volume of $25 \mu \mathrm{l}$, containing $1 \mathrm{X}$ PCR Gold Buffer, $1 \mathrm{mM}$ dNTP, $2 \mathrm{mM}$ $\mathrm{MgCl}_{2}, 10 \mathrm{pMol}$ forward CDH1-BSP (5'-TTTTAGTAATTT TAGGTTAGAGGGTTAT-3') and reverse $C D H 1$-BSP (5'-AAA CTCACAAATACTTTACAATTCC-3') oligonucleotides, 1 U AmpliTaq Gold ${ }^{\circledR}$ DNA Polymerase (cat. no. 4338856; Applied Biosystems; Thermo Fisher Scientific, Inc.) and $300 \mathrm{ng}$ bisulfite-treated DNA. The thermocycling conditions were as follows: $95^{\circ} \mathrm{C}$ for $7 \mathrm{~min}$, followed by 35 cycles of $95^{\circ} \mathrm{C}$ for $35 \mathrm{sec}, 57^{\circ} \mathrm{C}$ for $35 \mathrm{sec}$ and $72^{\circ} \mathrm{C}$ for $60 \mathrm{sec}$, and a final extension at $72^{\circ} \mathrm{C}$ for $7 \mathrm{~min}$. PCR products were treated using ExoI (cat. no. EN0581; Thermo Fisher Scientific, Inc.) and SAP (cat. no. EF0651; Thermo Fisher Scientific, Inc.) enzymes. The treated PCR products were sequenced using the BigDye ${ }^{\circledR}$ v3.1 Cycle Sequencing kit (cat. no. 4337455; Applied Biosystems; Thermo Fisher Scientific, Inc.) according to the manufacturer's protocol in an ABI PRISM ${ }^{\mathrm{TM}}$ 3100-Avant Genetic Analyzer (Applied Biosystems; Thermo Fisher Scientific, Inc.). The BSP oligonucleotides were designed by MethPrimer v2.0 software (The Li Lab; PUMCH; Chinese Academy of Medical Sciences) using GenBank sequence DQ335132.1 for the CDH1 gene (53). The sequencing data obtained from BSP were analyzed using Chromas v2.6.4 software (Technelysium Pty., Ltd.) and Lasergene v7 package (DNASTAR, Inc.).

$R N A$ extraction and reverse transcription-quantitative $(R T-q) P C R$. Total RNA was extracted from the treated and transfected cells using TRIzol ${ }^{\circledR}$ reagent (cat. no. 15596026; Invitrogen; Thermo Fisher Scientific, Inc.). The RNA was treated with DNase I (cat. no. EN0521; Invitrogen; Thermo Fisher Scientific, Inc.), and purified with Direct-zol ${ }^{\mathrm{TM}}$ RNA MicroPrep (cat. no. R2060; Zymo Research Corp.) according to the manufacturer's protocol. Complementary DNA (cDNA) was obtained from the purified RNA using the SuperScript ${ }^{\mathrm{TM}}$ IV First-Strand Synthesis system (cat. no. 18091050; Invitrogen; Thermo Fisher Scientific, Inc.) according to the manufacturer's protocol. The RNA-primer mix was incubated at $65^{\circ} \mathrm{C}$ for $5 \mathrm{~min}$ and $4^{\circ} \mathrm{C}$ for $1 \mathrm{~min}$, and the RT reaction mix was incubated at $55^{\circ} \mathrm{C}$ for $15 \mathrm{~min}$ and $80^{\circ} \mathrm{C}$ for $10 \mathrm{~min}$ to inactivate the reaction and placed on ice for subsequent use. Subsequently, 60 ng cDNA was subjected to qPCR to determine the expression levels of the genes of interest using the primers listed in Table I. qPCR conditions were as follows: $95^{\circ} \mathrm{C}$ for $10 \mathrm{~min}$, followed by 40 cycles of $95^{\circ} \mathrm{C}$ for $20 \mathrm{sec}, 60^{\circ} \mathrm{C}$ for $30 \mathrm{sec}$ and $72^{\circ} \mathrm{C}$ for $35 \mathrm{sec}$, and a final extension at $72^{\circ} \mathrm{C}$ for $7 \mathrm{~min}$. This was followed by a melting curve analysis at $65-95^{\circ} \mathrm{C}$. All qPCR assays were analyzed using Rotor-Gene Q Series v2.1.0 software (Qiagen, Inc.).

To obtain expression levels of CDH1, SNAI1, SNAI2, HPV16 E7 and HPV18 E7 in the HeLa, SiHa, Ca Ski and 
Table I. Primer sequences used for the BSP and qPCR assays.

\begin{tabular}{|c|c|c|}
\hline Gene & Assay & Primer sequences $\left(5^{\prime} \rightarrow 3^{\prime}\right)$ \\
\hline$C D H 1$ & $\mathrm{BSP}$ & $\begin{array}{l}\text { F: TTTTAGTAATTTTAGGTTAGAGG } \\
\text { GTTAT } \\
\text { R: AAACTCACAAATACTTTACAATT } \\
\text { CC }\end{array}$ \\
\hline $\mathrm{CDHI}$ & qPCR & $\begin{array}{l}\text { F: GTCAGTTCAGACTCCAGCCC } \\
\text { R: AAATTCACTCTGCCCAGGACG }\end{array}$ \\
\hline SNAII & qPCR & $\begin{array}{l}\text { F: ACCACTATGCCGCGCTCTT } \\
\text { R: GGTCGTAGGGCTGCTGGAA }\end{array}$ \\
\hline SNAI2 & qPCR & $\begin{array}{l}\text { F: GACCCTGGTTGCTTCAAGGA } \\
\text { R: TGTTGCAGTGAGGGCAAGAA }\end{array}$ \\
\hline E7 HPV16 & qPCR & $\begin{array}{l}\text { F: CAGCTCAGAGGAGGAGGATG } \\
\text { R: TGCCCATTAACAGGTCTTCC }\end{array}$ \\
\hline E7 HPV18 & qPCR & $\begin{array}{l}\text { F: TGAAATTCCGGTTGACCTTC } \\
\text { R: CACGGACACACAAAGGACAG }\end{array}$ \\
\hline GAPDH & qPCR & $\begin{array}{l}\text { F: AAGGTCGGAGTCAACGGATTTG } \\
\text { R: CCATGGGTGGAATCATATTGGAA }\end{array}$ \\
\hline$H P R T$ & qPCR & $\begin{array}{l}\text { F: GGACTAATTATGGACAGGACTG } \\
\text { R: GCTCTTCAGTCTGATAAAATCT } \\
\text { AC }\end{array}$ \\
\hline
\end{tabular}

BSP, bisulfite sequencing PCR; qPCR, quantitative PCR.

HaCaT cells, a commercial sample of RNA extracted from normal cervix negative for HPV (Human Cervix Total RNA; cat. no. AM6992; Ambion; Thermo Fisher Scientific, Inc.) was used as a reference. The $\triangle \mathrm{Cq}$ values for each gene were normalized to the reference gene $G A P D H$ using the $2^{-\Delta \Delta C q}$ method (54). The commercial sample of normal cervix negative for HPV was set as 1, and the results are not presented. For statistical analysis, the HaCaT cell line was used for comparison. For experiments involving the treatment of $\mathrm{HeLa}$ and SiHa cells with 5-AzadC and TSA, cells treated with DMSO were used as a reference, but data were not included in the graphs. For experiments involving the transfection of HeLa and SiHa cells with siRNAs, the cells treated with siPORT ${ }^{\mathrm{TM}}$ NeoFX $^{\mathrm{TM}}$ Transfection Agent with Opti-MEM ${ }^{\circledR}$ I were used as a reference, but results were not included in the graphs. $\triangle \mathrm{Cq}$ values of CDH1, SNAI1, SNAI2, HPV16 E7 and HPV18 E7 were normalized using the $2^{-\triangle \Delta \mathrm{Cq}}$ method (39) with $G A P D H$ as reference for 5-AzadC and TSA treatments, and HPRT as reference for experiments involving siRNA transfections. For statistical analysis, untreated (Unt) HeLa and SiHa cells were used for comparisons.

Protein extraction and western blot analysis. Proteins were obtained using a lysis buffer containing $5 \mathrm{mM}$ EDTA, $150 \mathrm{mM} \mathrm{NaCl}, 5 \mathrm{mM}$ Tris- $\mathrm{HCl} \mathrm{pH}$ 9.0, 1\% Nonidet-P40 and $1.2 \mathrm{mg} / \mathrm{ml} \mathrm{cOmplete}{ }^{\mathrm{TM}}$ protease inhibitor cocktail (Roche Applied Science). Protein extracts were forced through a 22-gauge needle 10 times and centrifuged for $10 \mathrm{~min}$ at $17,000 \mathrm{x} g$ at $4^{\circ} \mathrm{C}$. Protein concentration was determined using the Bradford method. Subsequently, $30 \mathrm{mg}$ protein was loaded and separated on $12 \%$ SDS-PAGE gels followed by transfer to nitrocellulose membranes. Membranes were blocked with 5\% nonfat dry milk in $1 \mathrm{X}$ TBS with $0.1 \%$ Tween-20 (TBST) at $4^{\circ} \mathrm{C}$ for $1 \mathrm{~h}$ with gentle agitation and incubated overnight at $4^{\circ} \mathrm{C}$ with antibodies against E-cadherin (cat. no. sc-8426; 1:1,000), GAPDH (cat. no. sc-48167; 1:1,000), $\beta$-actin (cat. no. sc-1616; 1:1,000; all from Santa Cruz Biotechnology, Inc.), Snai1 (cat. no. L70G2; 1:1,000; Cell Signaling Technology, Inc.) and Snai2 (cat. no. C19G7; 1:1,000; Cell Signaling Technology, Inc.) diluted in TBST with 5\% BSA (cat. no. 9998; Cell Signaling Technology, Inc.). Subsequently, membranes were incubated with secondary antibodies for $2 \mathrm{~h}$ at room temperature, including goat anti-mouse IgG-horseradish peroxidase (HRP; cat. no. sc-2005; 1;10,000), donkey anti-rabbit IgG-HRP (cat. no. sc-2313; 10,000) and donkey anti-goat IgG-HRP (cat. no. sc-2020; 1:5,000; all from Santa Cruz Biotechnology, Inc.) diluted in TBST with 5\% non-fat dry milk. Immobilon Western Chemiluminescent HRP substrate (EMD Millipore) was used for protein detection, and images were acquired using C-DiGit Blot scanner equipment (Li-Cor Biosciences) and processed in the Image Studio ${ }^{\mathrm{TM}}$ Lite version 5.2 software (Li-Cor Biosciences).

Nitrocellulose membranes were incubated with two primary antibodies in the following manner: i) Incubation was performed as described against a primary antibody, including E-cadherin, Snail or Snai2 with their respective secondary antibody; ii) images were acquired; iii) membranes were washed $3 \times 5 \mathrm{~min}$ with $\mathrm{TBST}$ at room temperature; iv) membranes were re-probed with a second primary antibody, including GAPDH or $\beta$-actin with their respective secondary antibody; and v) images were acquired.

Statistical analysis. Statistical analysis was performed using GraphPad Prism v4.0 (GraphPad Software, Inc.). One-way ANOVA with Turkey's post hoc test were used to evaluate significant differences in gene expression and methylation levels, and results were presented as the mean \pm SD. $\mathrm{P}<0.05$ was considered to indicate a statistically significant difference.

\section{Results}

Different methylation patterns in the CDH1 promoter region are present in HPV16- and HPV18-positive cancer cell lines. A common site-specific methylation pattern in certain $\mathrm{CpG}$ islands $(-160,-150,-131$ and -122) of the $C D H 1$ promoter region was detected in $\mathrm{HeLa}$ and $\mathrm{SiHa}$ cells, whereas other CpG islands $(-45,-136,-105,-103,-83,-57,-52,-45,-36,-13$, +6 and +9 ) were identified to be methylated in HeLa only (Fig. 1B). Of note, Ca Ski cells did not exhibit methylation of any of the $17 \mathrm{CpG}$ sites of the $\mathrm{CDH1}$ promoter that were analyzed (Fig. 1B). Quantification of the methylation levels in the $C D H 1$ promoter region indicated that HeLa presented a methylation frequency of $88.24 \%$, SiHa cells exhibited a methylation frequency of $17.65 \%$ and Ca Ski cells demonstrated no methylation (frequency, 0\%; Fig. 1C).

Based on previous studies (25-28), initial experiments were conducted using the C33-A, C33-A transfected with pE7/HPV16 (C33-A pE7/HPV16), MCF-7 and MCF-7 transfected with pE6/E7 from HPV18 (MCF-7 pE6/E7) cell lines as HPV-negative cancer models. Validation of C33-A and MCF-7 cell stable clone selection with pE7/HPV16 

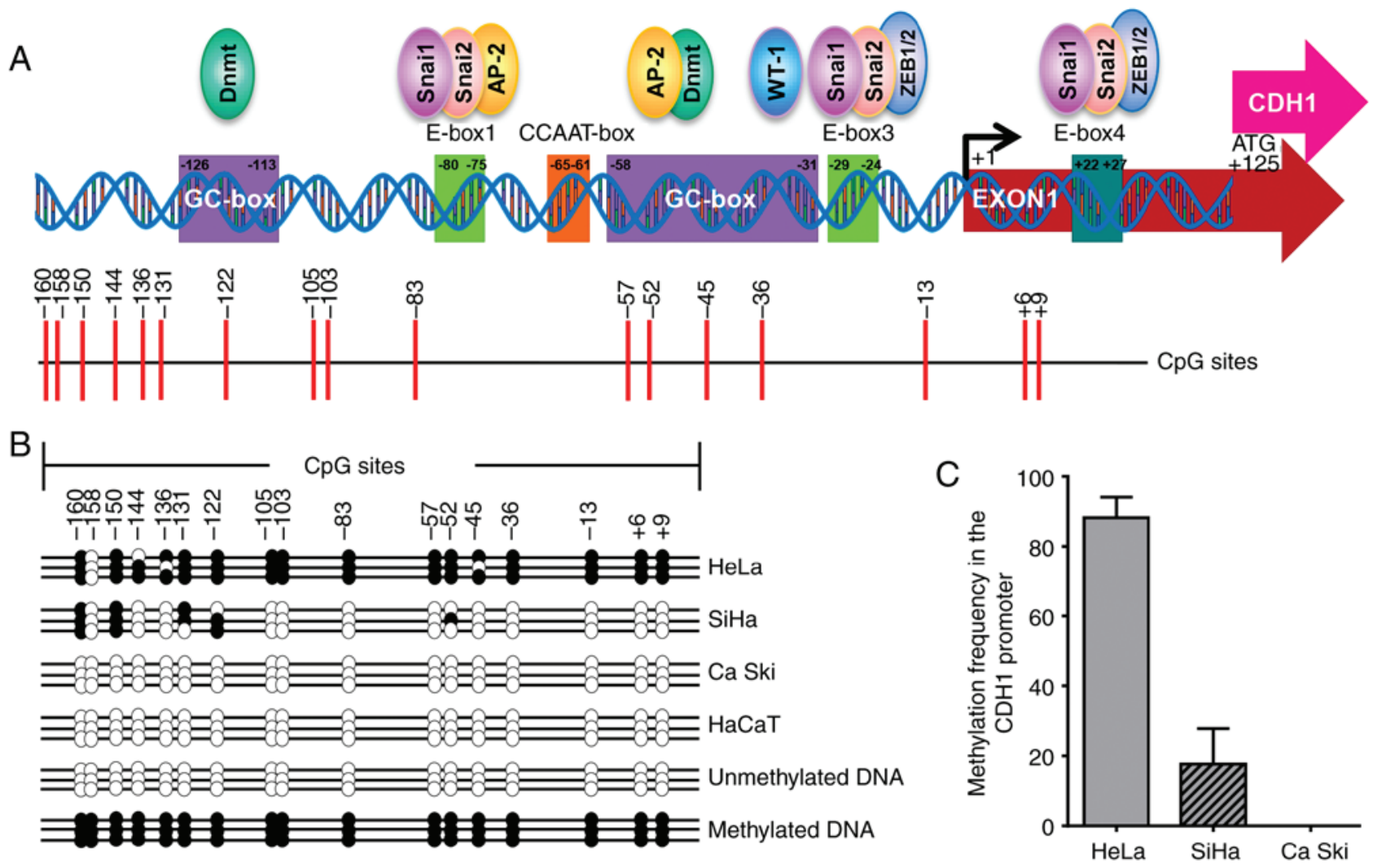

- Methylated CpG; O Unmethylated CpG
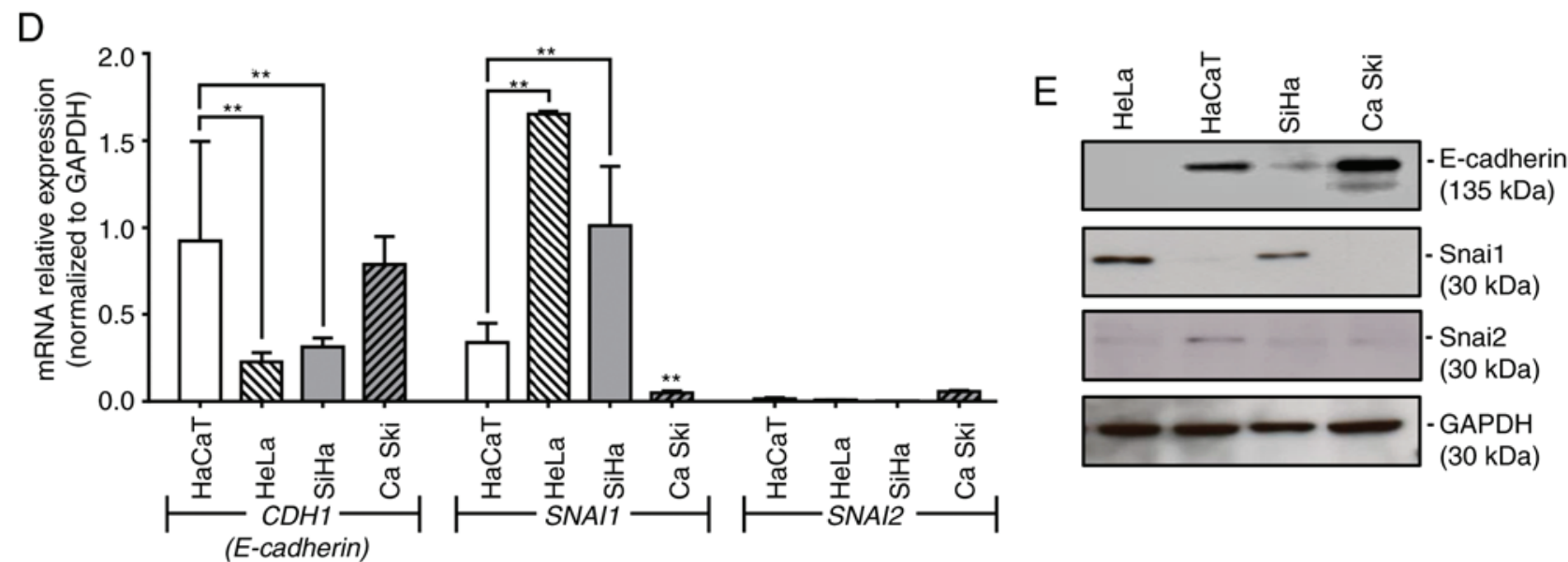

Figure 1. Methylation of the $\mathrm{CDH} 1$ gene promoter region. (A) The location of different elements; the E-box and GC box motifs that regulate transcription of $C D H 1$. Red vertical lines indicate each CpG site contained in the promoter region. (B) A lollipop methylation diagram of bisulfite sequencing of the $\mathrm{CDH1}$ promoter in the $\mathrm{HeLa}, \mathrm{SiHa}, \mathrm{Ca} \mathrm{Ski}$ and $\mathrm{HaCaT}$ cell lines. Black indicates a methylated $\mathrm{CpG}$ site; white indicates an unmethylated $\mathrm{CpG}$ site. (C) Quantification of the methylation frequency of the $\mathrm{CDH1}$ promoter in the HeLa, SiHa and Ca Ski cell lines. (D) Quantitative PCR was performed to measure the expression levels of $C D H 1$, SNAII and SNAI2 genes in the indicated cell lines. " $\mathrm{P}<0.05$ and ${ }^{* *} \mathrm{P}<0.01$ vs. HaCaT. (E) Protein expression levels of E-cadherin, Snail and Snai2 were assessed by western blot analysis in HPV-positive cell lines. GAPDH was used as a loading control. CDH1, cadherin 1; Dmnt1, DNA methyltransferase 1; AP-2, activating protein 2; ZEB1/2, zinc finger E-box-binding homeobox 1/2.

and pE6/E7, respectively, was performed by evaluating E7 mRNA expression by RT-PCR (Fig. S1B). However, C33-A vs. C33-A pE7/HPV16 and MCF-7 vs. MCF-7 pE6/E7 did not exhibit any differences in the methylation of $\mathrm{CDH} 1$ promoter regions (Fig. S1 A) or in the expression of $\mathrm{CDH1}$ at mRNA and protein levels (Fig. S1B and C). As the MCF-7 cell line is an adenocarcinoma that derives from the mammary gland and exhibits an epithelial phenotype with a high expression level of $\mathrm{CDH} 1$, similar to that observed in Ca Ski cells, and since the C33-A cell line originally does no express CDH1, C33-A and
MCF7 cells were eliminated from the study; neither the effect of oncoprotein E7 on the suppression of $\mathrm{CDHI}$ expression, nor the methylation patterns in the $\mathrm{CDH} 1$ promoter could be evaluated in these cells.

Methylation levels in the $\mathrm{CDH1}$ promoter are associated with the $m R N A$ and protein expression levels of $C D H 1$. Analysis of $C D H 1$ expression in the different cell lines demonstrated a significant decrease of the $C D H 1$ mRNA level in the HeLa $(\mathrm{P}<0.001)$ and SiHa $(\mathrm{P}<0.01)$ cell lines compared 
A

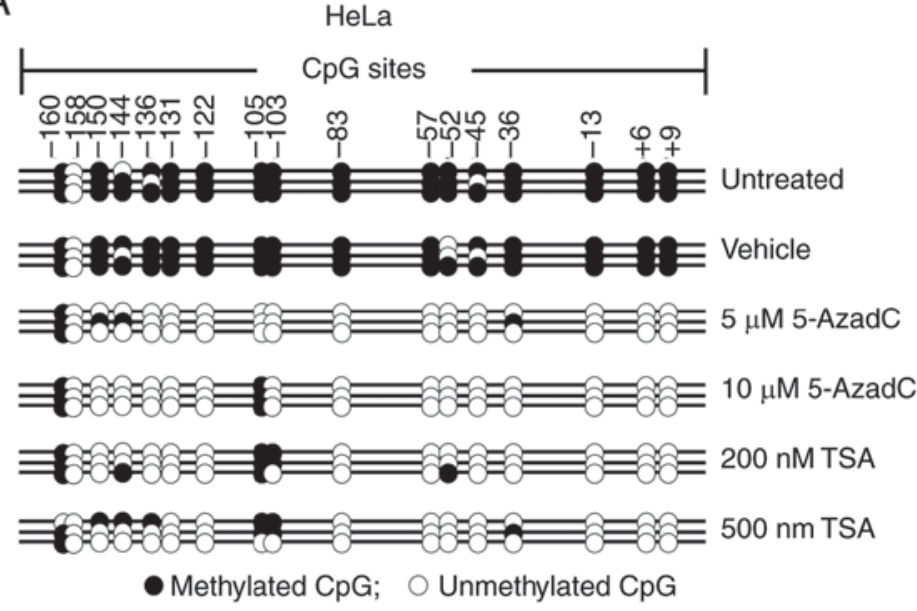

C

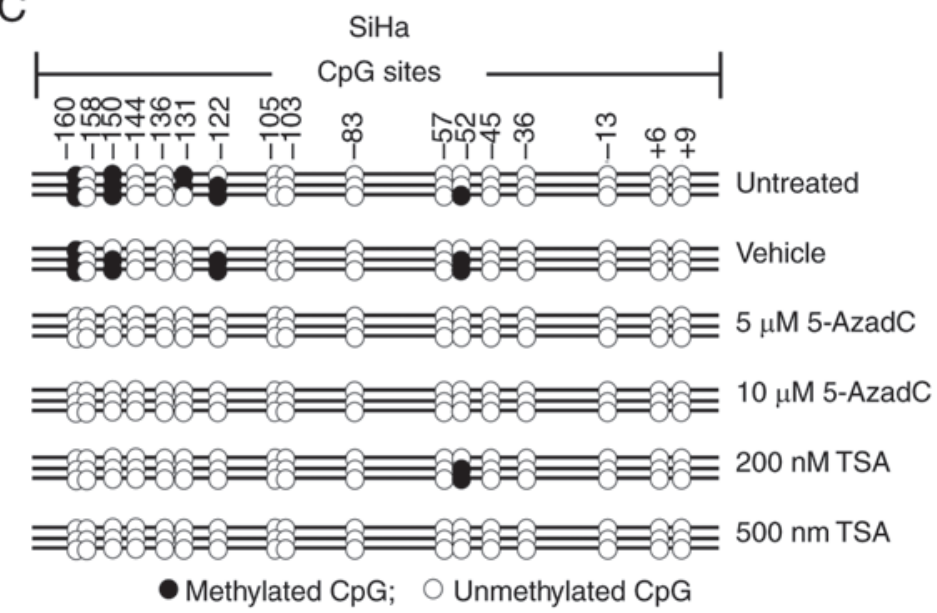

B

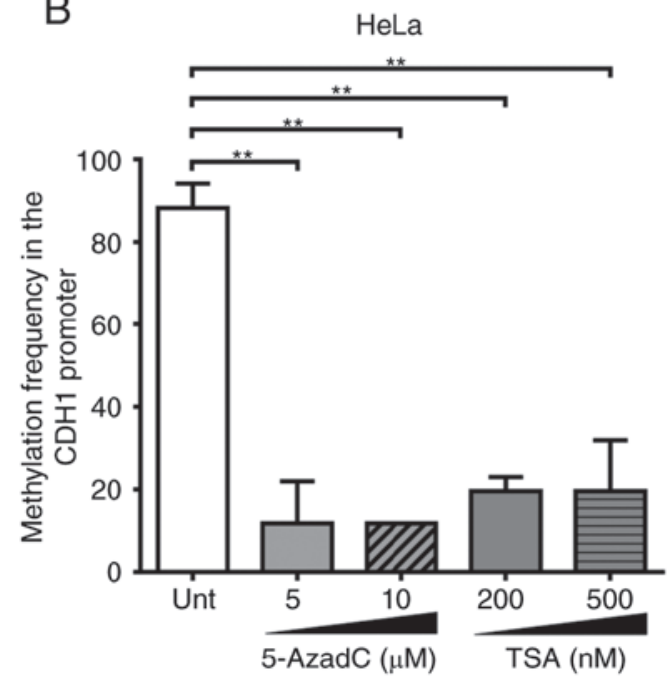

D

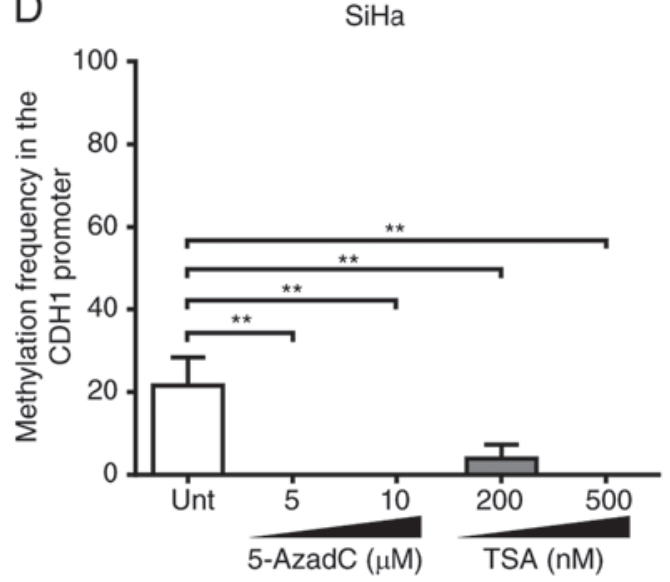

Figure 2. Changes in the methylation pattern of the $C D H 1$ promoter in HeLa and SiHa cell lines following treatment with 5-AzadC and TSA. (A and C) Lollipop methylation diagrams demonstrating changes in the methylation pattern in $\mathrm{CpG}$ sites of the $\mathrm{CDH}$ 1 promoter region in (A) HeLa and (C) SiHa cell lines following treatments with 5-AzadC and TSA compared with Unt and vehicle-treated cells. Black indicates a methylated CpG site; white indicates an unmethylated CpG site. (B and D) Quantification of the methylation frequency of the CDH1 promoter in (B) HeLa and (D) SiHa cell lines following treatment with the indicated concentrations of 5-AzadC and TSA compared with untreated cells. ${ }^{* *} \mathrm{P}<0.01$ vs. untreated cells. Unt, untreated; $C D H 1$, cadherin 1 ; 5-AzadC, 5-aza-2'-deoxycytidine; TSA, trichostatin A.

with the HaCaT cell line (Fig. 1D). A similar decrease was observed at the protein level (Fig. 1E). By contrast, the $\mathrm{Ca}$ Ski cell line exhibited high $\mathrm{CDH} 1$ expression, similar to the control $\mathrm{HaCaT}$ cell line, at the mRNA and protein level (Fig. 1D and E).

CDH1 expression level is associated with the expression level of SNAII. The present study measured the expression of SNAII and SNAI2 to test the hypothesis that the expression of $\mathrm{CDH} 1$ is regulated by the transcription factors Snail and Snai2, which mediate EMT by negatively regulating the expression of $\mathrm{CDH}$ (27,55-57). The results revealed that the mRNA expression level of SNAII is significantly increased in HeLa $(\mathrm{P}<0.0001)$ and SiHa cells $(\mathrm{P}<0.001)$, but significantly reduced in $\mathrm{Ca}$ Ski cells $(\mathrm{P}<0.01)$ compared with $\mathrm{HaCaT}$ cells (Fig. 1D). This result was also reflected at the protein level (Fig. 1E). No significant differences were observed in the expression of SNAI2 at the mRNA (Fig. 1D) and protein (Fig. 1E) level among all cell lines. Since the Ca Ski cell line exhibits a non-mesenchymal phenotype, a high expression level of E-cadherin and low expression levels of Snail and Snai2, this cell line was excluded from further analysis.

Treatment with 5-AzadC and TSA affect methylation and re-expression of $C D H 1$. HeLa and $\mathrm{SiHa}$ cells were treated with different concentrations of 5-AzadC and TSA, followed by analysis of the expression levels of $C D H 1$, SNAI1, and SNAI2. HeLa and SiHa cells treated with the vehicle (DMSO) were used for normalizing the expression values, as well for performing comparisons in statistical analysis.

The results demonstrated that in the HeLa cell line, the methylation pattern was maintained at $\mathrm{CpG}$ sites $-103,-105$, and -160 of the $C D H 1$ promoter region following treatment with 5-AzadC and TSA. By contrast, in the SiHa cell line, this region was completely demethylated following treatment with 5 or $10 \mu \mathrm{M} 5$-AzadC or $500 \mathrm{nM}$ TSA, and only CpG site -52 was methylated following treatment with $200 \mathrm{nM}$ TSA (Fig. 2A and C). Compared with untreated HeLa and SiHa cells, a decrease in methylation of $76.48 \%$ was observed following 5 or $10 \mu \mathrm{M} 5$-AzadC treatment, whereas following 

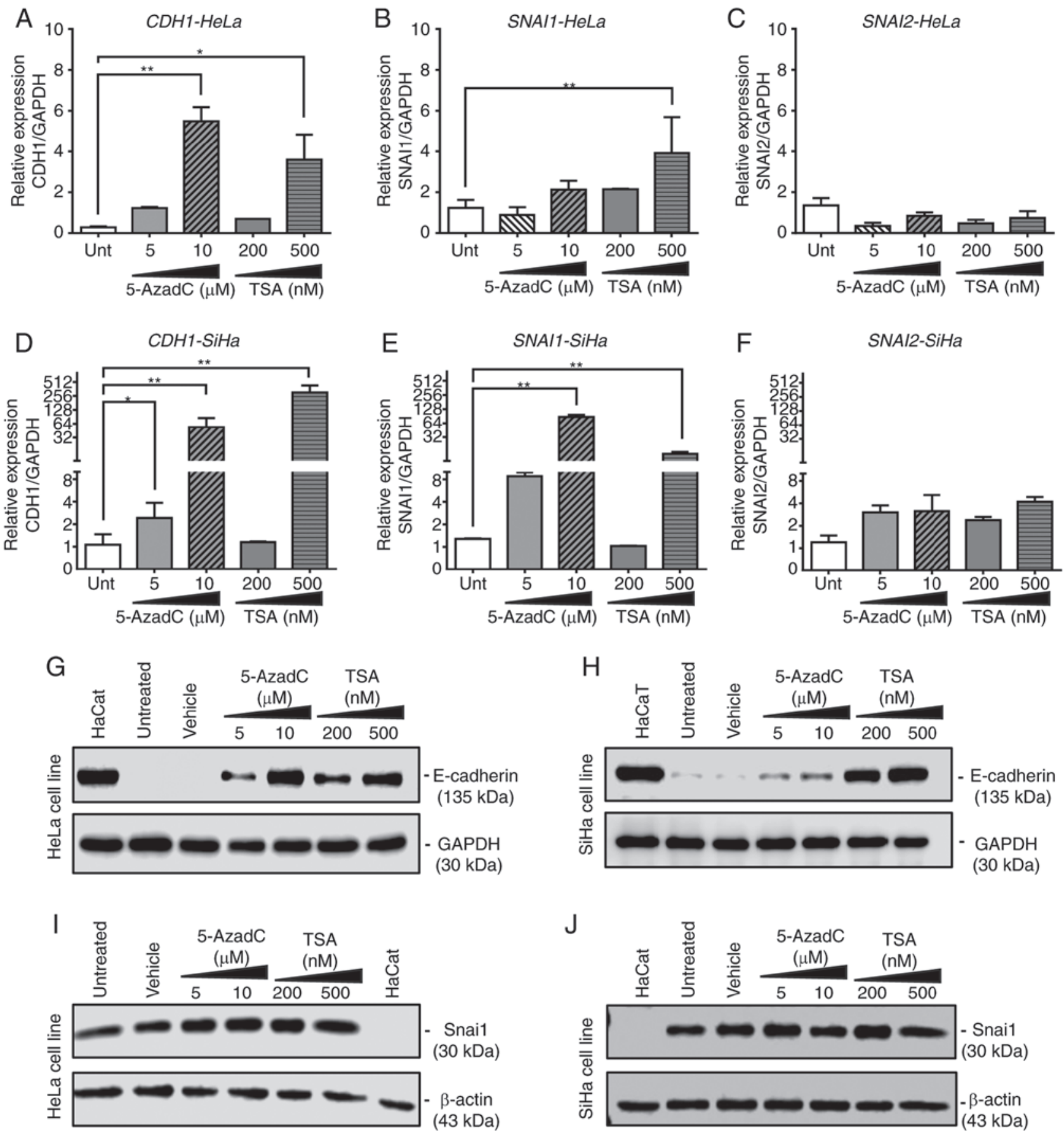

Figure 3. Changes in the expression levels of CDH1, SNAI1 and SNAI2 in HeLa and SiHa cells following treatment with 5-AzadC and TSA. (A-F) Quantitative PCR analyses of CDH1, SNAI1 and SNA2 mRNA expression levels in (A-C) HeLa and (D-F) SiHa cells following treatments with 5-AzadC and TSA compared with untreated cells; ${ }^{*} \mathrm{P}<0.05$ and $^{* *} \mathrm{P}<0.01$ vs. untreated cells. (G and H) Protein expression of E-cadherin in $(\mathrm{G}) \mathrm{HeLa}$ and $(\mathrm{H}) \mathrm{SiHa}$ cell lines. (I and J) Protein expression of Snail in (I) HeLa and (J) SiHa cell lines following the indicated treatments. Unt, untreated; $C D H 1$, cadherin 1; 5-AzadC, 5-aza-2'-deoxycytidine; TSA, trichostatin A.

treatment with 200 or $500 \mathrm{nM}$ TSA, a decrease in methylation of $68.63 \%$ was observed. By contrast, in SiHa cells, a decrease of $21.57 \%$ was observed following treatment with 5 or $10 \mu \mathrm{M}$ 5 -AzadC or $500 \mathrm{nM}$ TSA, whereas following treatment with $200 \mathrm{nM}$ TSA, a $17.65 \%$ decrease in methylation was observed. Therefore, it was demonstrated in the two cell lines that treatment with 5-AzadC or TSA significantly diminished the level of $C D H 1$ methylation $(\mathrm{P}<0.001$; Fig. $2 \mathrm{~B}$ and $\mathrm{D})$. However, no significant differences were observed between the two treatments in diminishing the methylation levels of $\mathrm{CDH} 1$.
In the HeLa cell line, treatments with $10 \mu \mathrm{M}$ 5-AzadC $(\mathrm{P}=0.004)$ and $500 \mathrm{nM}$ TSA $(\mathrm{P}=0.03)$ significantly increased the expression of $\mathrm{CDH} 1 \mathrm{mRNA}$ and protein (Fig. 3A and $\mathrm{G}$ ). In addition, $500 \mathrm{nM}$ TSA significantly increased the mRNA expression of SNAII ( $\mathrm{P}=0.01$, Fig. 3B) in HeLa cells without notable changes in protein expression (Fig. 3I). In the $\mathrm{SiHa}$ cell line, the mRNA expression of $C D H 1$ significantly increased following treatment with 5 -AzadC at 5 and $10 \mu \mathrm{M}(\mathrm{P}<0.05$ and $\mathrm{P}<0.01$, respectively) or $500 \mathrm{nM}$ TSA ( $\mathrm{P}=0.004$; Fig. 3D); a similar effect was observed at the protein level (Fig. $3 \mathrm{H}$ ). 
A

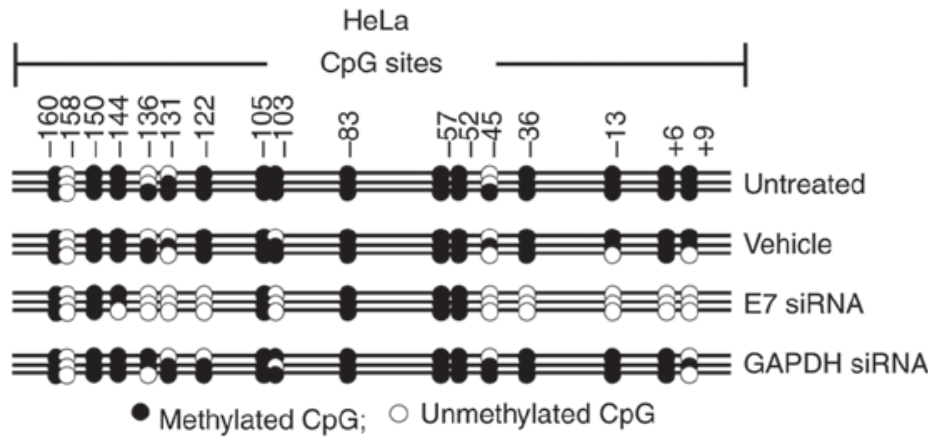

C

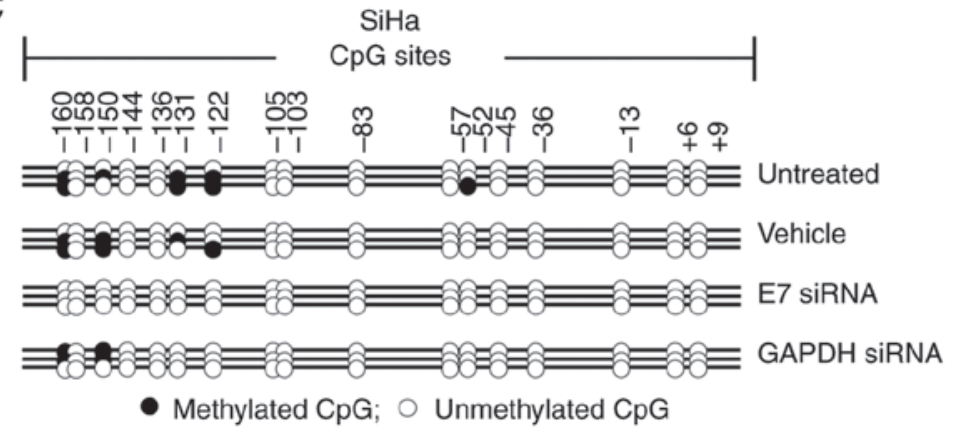

B
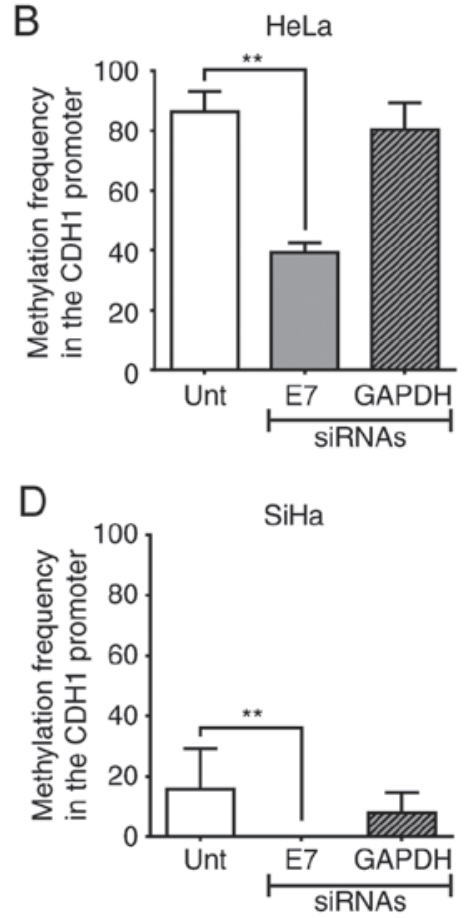

Figure 4. Silencing of E7 from HPV18 and HPV16 modifies the methylation pattern of the CDH1 promoter in HeLa and SiHa cells. (A and C) Lollipop methylation diagrams demonstrating changes in the methylation pattern in $\mathrm{CpG}$ sites of the $\mathrm{CDH1}$ promoter region in (A) HeLa and (C) SiHa cell lines following transfection with siRNA targeting $E 7$ and $G A P D H$ compared with Unt and vehicle control cells. Black indicates a methylated CpG site; white indicates an unmethylated $\mathrm{CpG}$ site. (B and D) Methylation frequency of the $\mathrm{CDH1}$ promoter in (B) HeLa and (D) SiHa cells following transfection with siRNA targeting $E 7$ from HPV18, E7 from HPV16 and GAPDH compared with untreated cells. ${ }^{* *} \mathrm{P}<0.01$ vs. untreated cells. $C D H 1$, cadherin 1; Unt, untreated; siRNA, small interfering RNA; HPV, human papilloma virus.

In addition, the expression of SNAII mRNA was significantly increased following treatment with $10 \mu \mathrm{M} 5-\mathrm{AzadC}(\mathrm{P}=0.004)$ or $500 \mathrm{nM}$ TSA $(\mathrm{P}=0.01)$ (Fig. 3E) in SiHa cells without notable changes at the protein level (Fig. 3J), similar to that observed in HeLa.

5-AzadC and TSA also increased the mRNA expression level of SNAII in the HeLa (Fig. 3B) and SiHa cell lines (Fig. 3E); however, no changes were observed in SNAI1 protein levels in the two cell lines (Fig. 3I and J). The expression of SNAI2 was not significantly modified at the mRNA level under any treatment condition in the tested cell lines (Fig. 3C and F).

Suppression of E7 by siRNA modifies the methylation patterns of the CDH1 promoter and induces CDH1 expression in HeLa and SiHa cell lines. To examine the involvement of E7 in the $\mathrm{CDH} 1$ methylation and expression patterns, HeLa and $\mathrm{SiHa}$ cell lines were transfected with siRNA against E7, which resulted in 57.9 and $42.5 \%$ reduction in the $E 7$ mRNA level, respectively (Fig. 5A and C). In the HeLa cell line, E7 silencing led to demethylation of $\mathrm{CDHl} \mathrm{CpG}$ promoter sites located between +9 and -45 , as well as at -103 and between -122 and -136 (Fig. 4A). In addition, in the SiHa cell line, total demethylation of the $\mathrm{CDH} 1$ promoter was observed following E7 silencing (Fig. 4C). Therefore, partial silencing of E7 in $\mathrm{HeLa}$ and SiHa cells yielded a significant decrease in $\mathrm{CDHI}$ promoter methylation compared with untreated control cells $(\mathrm{P}<0.001$; Fig. 4B and D). Increased $C D H 1$ mRNA and protein levels were observed following $E 7$ silencing in HeLa (Fig. 5B and F) and SiHa (Fig. 5B and G) cells. The use of
Silencer ${ }^{\circledR}$ Select GAPDH siRNA as a positive control siRNA excluded the possibility that changes in the methylation pattern of the $C D H 1$ promoter were due to the siRNA transfection conditions as GAPDH silencing did not induce significant changes in the methylation pattern of the $C D H 1$ promoter in HeLa ( $\mathrm{P}=0.7140$; Fig. 4B) and $\mathrm{SiHa}(\mathrm{P}=0.3248$; Fig. 4D) cells; therefore, the changes in the methylation pattern were likely due to $E 7$ silencing.

Suppression of E7 inhibits SNAII and SNAI2 expression in HeLa and SiHa cells. Silencing of E7 not only induced the expression of $C D H 1$, but also significantly decreased the expression of SNAII and SNAI2 $(\mathrm{P}<0.001)$ in HeLa and SiHa cells (Fig. 5D, E, H and I). This suggested that E7 may be not only involved in suppressing the expression of $\mathrm{CDH}$, but may also regulate the expression of SNAII and SNAI2, which negatively regulate $\mathrm{CDH} 1$. No significant changes were observed in the mRNA expression of E7, CDH1, SNAII and SNAI2 following GAPDH silencing in HeLa and SiHa cells (P>0.5; Fig. 5A, B, D and E). However, silencing of GAPDH with siRNA resulted in a decrease in the protein expression of Snail in HeLa cells (Fig. 5H).

As housekeeping genes GAPDH and HPRT were used to normalize the expression levels of the genes studied, no significant differences were noted in the reduction of SNAII expression at the mRNA level (Fig. 5D). Further analysis of the expression levels of GAPDH, CDHI and SNAII genes normalized against $\beta$-actin demonstrated that $G A P D H$ expression was 2.6-fold higher in HaCaT, 1.6-fold higher in HeLa, 3.3-fold higher in SiHa and 3.8-fold higher in Ca Ski cells 


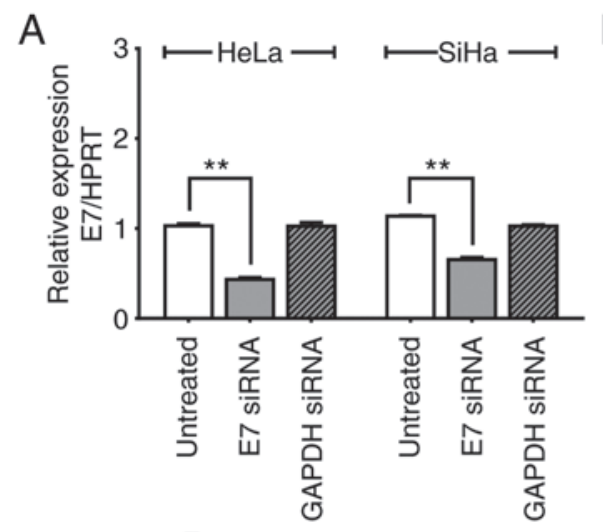

D

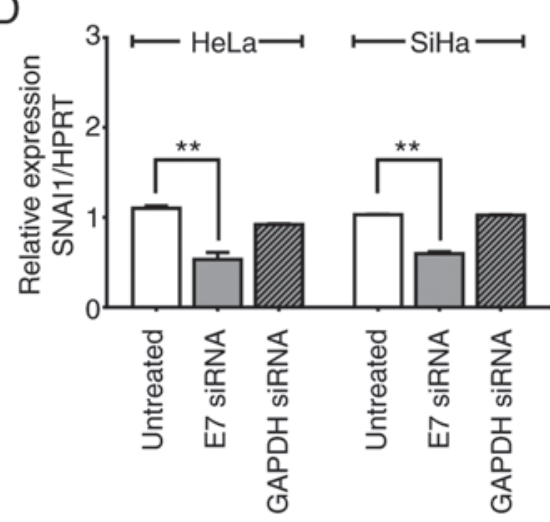

$\mathrm{F}$
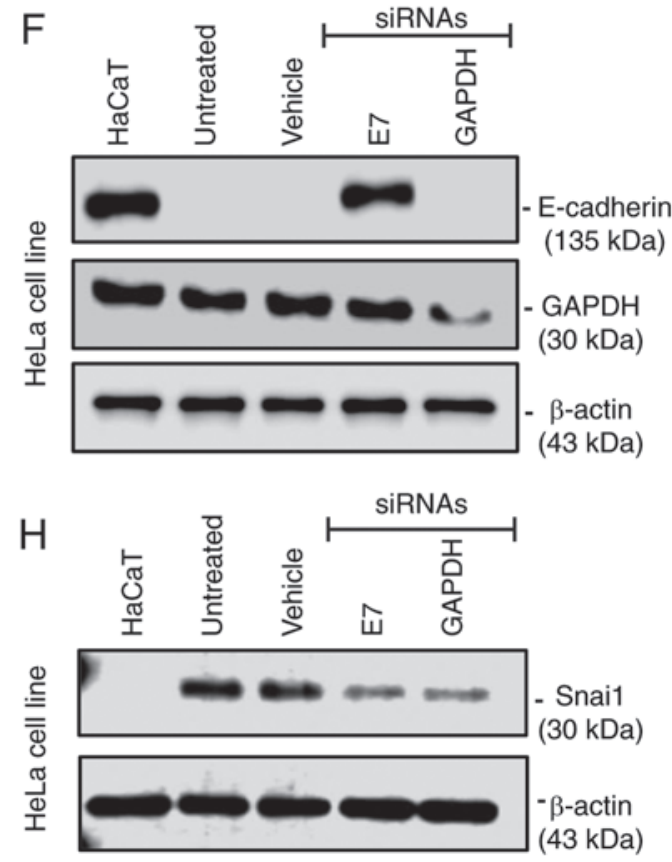

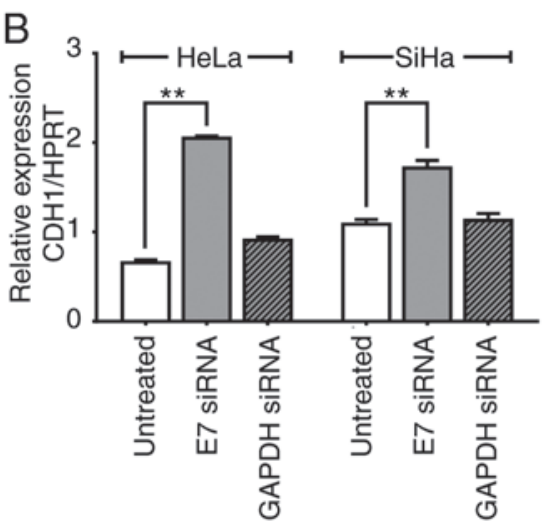

E

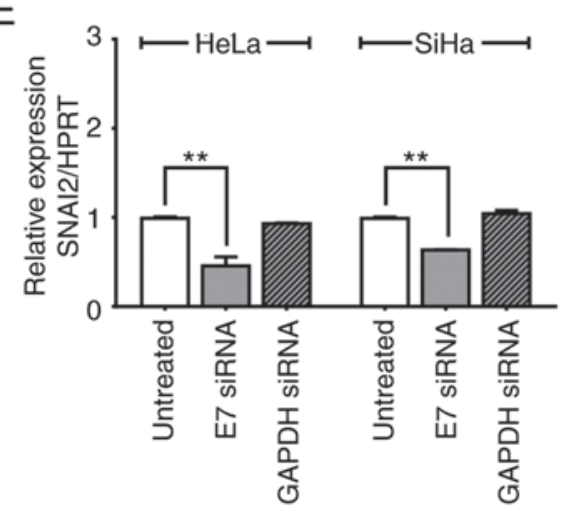

G
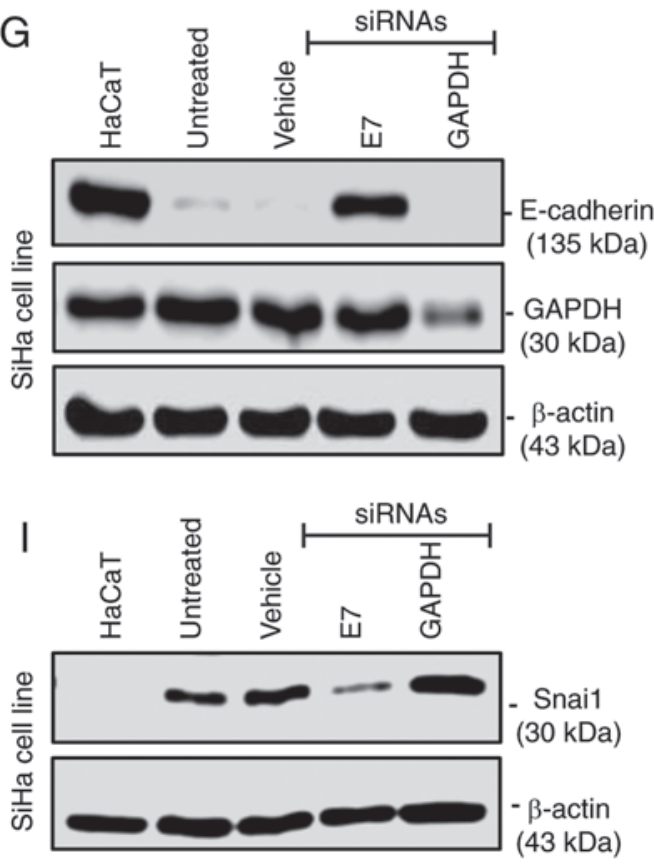

Figure 5. Silencing of E7 from HPV18 and HPV16 modifies the expression of CDH1 and SNAI1 genes in HeLa and SiHa cell lines. (A-E) The relative mRNA expression levels of (A) E7, (B) CDH1, (C) GAPDH, (D) SNAI1 and (E) SNAI2 in HeLa and SiHa cell lines following transfection with siRNA against E7 and GAPDH. ${ }^{* *} \mathrm{P}<0.01$ vs. untreated cells. E-cadherin, Snai1, GAPDH and $\beta$-actin protein expression levels in (F and H) HeLa and (G and I) SiHa cells following transfection with siRNA targeting $E 7$ and $G A P D H$. CDH1, cadherin 1; siRNA, small interfering RNA; HPV, human papilloma virus.

compared with a commercial sample of RNA extracted from normal cervical tissue (Fig. S2).

\section{Discussion}

HR-HPV activates the cell methylation machinery, which not only methylates its own genome, but also the promoter regions of cellular genes (21). Laurson et al (26) have demonstrated that E7 induces the expression of Dnmt1 and suppresses the expression of $\mathrm{CDH} 1$. Reduction of E-cadherin has been reported to contribute to the persistence of HPV, which is in agreement with reports that E7 interacts with and induces the expression of Dnmt1 and triggers its de novo methylation activity (16) (Fig. 6A). The results of the present study agree 


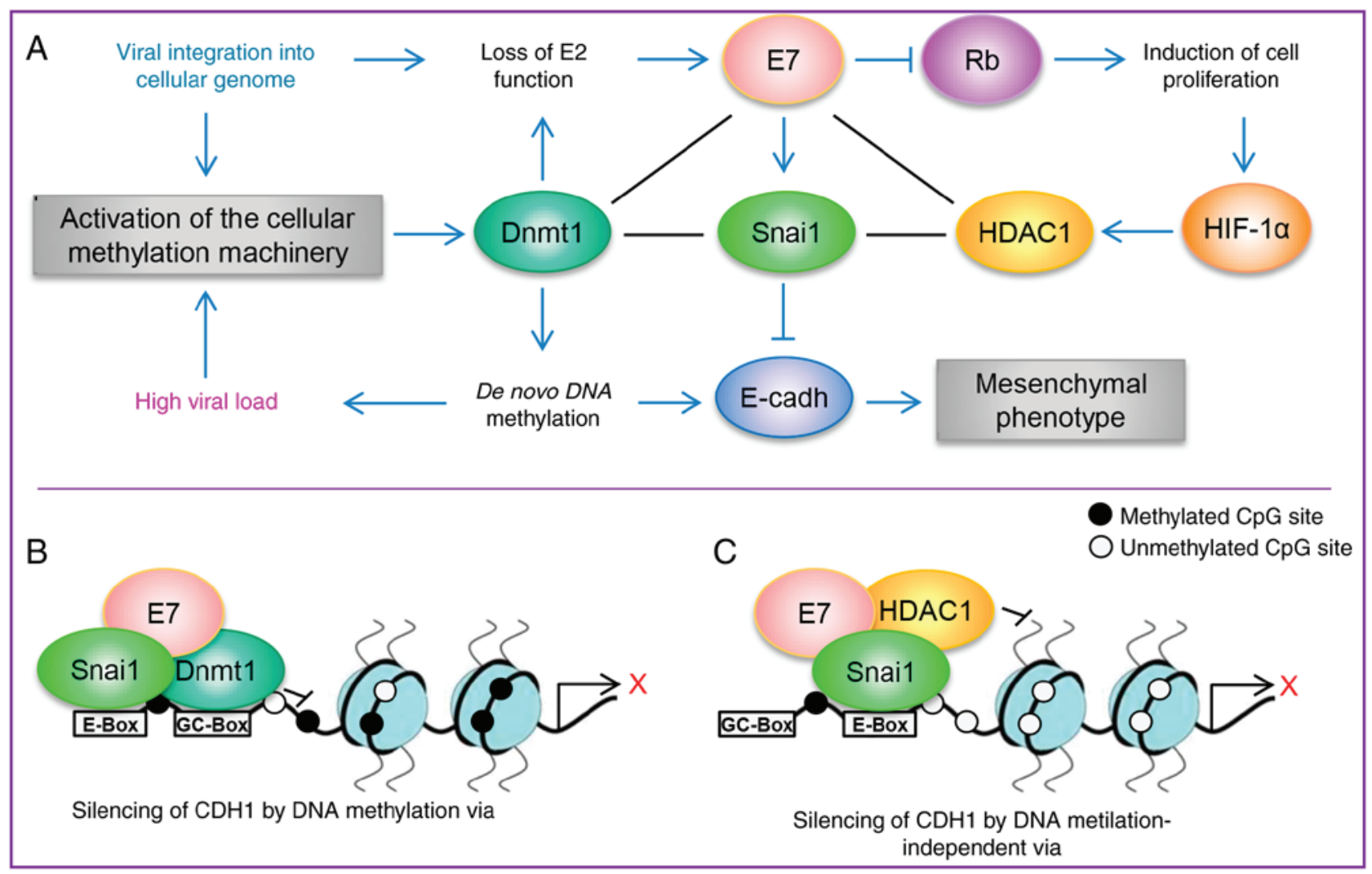

Figure 6. A schematic model demonstrating how high-risk HPV E7 may induce epithelial-mesenchymal transition via Snail. (A) A schematic model of proteins that interact with or are induced by E7. The loss of E2 function, either from the integration or methylation of the E2 binding sites in the HPV long control region, leads to the dysregulated expression of the oncoproteins E6 and E7. E7 serves an important role in regulating several pathways; E7 induces cellular proliferation via pRB and E7 not only induces the expression of Dnmt1 and HDAC1, but also physically interacts with them, which promotes epigenetic regulation of HPV and cellular genes. The results of the present study indicated that E7 may not only suppresses the expression of $\mathrm{CDH} 1$ through the methylation of its promoter region, but also induce the expression of Snail, which is a negative regulator of $\mathrm{CDH} 1$ expression. (B and C) Proposed models of how E7 may regulate the expression of $C D H 1$. HPV, human papilloma virus; $C D H 1$, cadherin 1; Dmnt1, DNA methyltransferase 1; HDAC1, histone deacetylase type 1; HIF-1 $\alpha$, hypoxia-inducible factor $1 \alpha$; pRB, retinoblastoma protein.

with previous findings by Laurson et al (26), in which $\mathrm{E} 7$ from HPV16 suppressed the expression of $C D H 1$. However, in this previous study, no significant differences were observed in the methylation pattern of the $C D H 1$ promoter of NIKS cells overexpressing E7, as the $17 \mathrm{CpG}$ sites analyzed were not methylated (23). In addition, treatment with 5-AzadC re-established the expression of $\mathrm{CDH} 1$ at the mRNA and protein levels (26); however, the concentration of 5-AzadC used was not stated and the changes in the expression of other cellular genes were not discussed.

The present study evaluated the re-expression of $\mathrm{CDH}$ at the mRNA and protein levels in HeLa and $\mathrm{SiHa}$ cell lines treated with 5-AzadC and TSA, as well as changes in the methylation pattern of the promoter region of $C D H 1$. Additionally, although TSA is not a demethylating agent, demethylation in the promoter of $\mathrm{CDH} 1$ following treatment with TSA was observed. This result was an agreement with previous studies that have reported that TSA induces DNA demethylation and proposed that a change in chromatin modification, including the deacetylation of histones induced by an HDAC inhibitor, such as TSA, may render a gene susceptible to DNA demethylation $(58,59)$.

In addition, an increase in SNAII mRNA level was observed after treatment with $500 \mathrm{nM}$ TSA in HeLa cells, whereas in SiHa cells an increase in SNAII mRNA level was observed after treatment with $10 \mu \mathrm{M} 5$-AzadC and $500 \mathrm{nM}$ TSA; however, no apparent changes were observed in SNAI1 protein level in the two cell lines. This result was in agreement with studies in which such treatments not only re-established the expression of $C D H 1$, but also induced upregulation of SNAII and SNAI2 at the mRNA level $(60,61)$, which was likely due to modifications in the methylation pattern in the promoter regions of SNAII and SNAI2 (62). The role of SNAII regulation by epigenetic mechanisms is largely unknown. A previous study has demonstrated that the treatment with 5-AzadC in fibroblast cell IMR90, induced pluripotent stem cells from IMR90, BeWo and HTR8/SVneo cell lines induces a greater expression of SNAII and SNAI2 at the mRNA level and that the regulation of the two genes is mediated by DNA methylation of their first intron and not due to DNA methylation of their promoter region; however, this previous study did not determine the expression of these genes at the protein level (62). The present study did not determine the methylation status of the SNAII promoter region as it is transcriptionally active in HeLa and SiHa cells. The differences observed in the effect on SNAI1 expression at the mRNA and protein levels by treatment with 5-AzadC and TSA indicated that other factors may regulate the expression of SNAI1 in the two cell lines.

On the other hand, the results published by Laurson et al (26) suggested that in the NIKS-cell model, suppression of $\mathrm{CDH1}$ 
expression by E7 was independent of the methylation status of the $C D H 1$ promoter region, which was observed in the $\mathrm{SiHa}$ cell line in the current study. The previous study also suggested that repression of $C D H 1$ may be regulated via SNAI2 (SLUG); however, it was reported that the expression of SNAI2 was not altered by the presence of E7 (26). The results of the present study revealed that while SNAII mRNA and protein was expressed in HeLa and SiHa cells, SNAI2 mRNA expression was barely detectable in $\mathrm{HaCaT}$ and Ca Ski cells. SNAI2 has been demonstrated to be upregulated in $\mathrm{HaCaT}$ cells during the process of cell motility and wound-healing (63).

The results of the present study demonstrated that following silencing of $E 7$ from HPV16 and HPV18, $C D H 1$ expression was recovered in HeLa and $\mathrm{SiHa}$ cells, which is in agreement with a previous study by Caberg et al (25). This previous study reported that following 24-h transfection of SiHa cells with siRNA against HPV16 E7, CDH1 was upregulated and an increase of the Retinoblastoma protein (pRB), which is responsible for a major G1 check point, blocking $\mathrm{S}$-phase entry and cell growth, and activating protein $2 \alpha$ were detected without changes in the mRNA expression levels of SNAII and SNAI2 (25). By contrast, the present study demonstrated that following 48-h transfection with siRNA against $E 7$, changes in the methylation pattern of the $C D H 1$ promoter region were observed in HeLa and SiHa cells. In addition, an increase in the mRNA and protein expression levels of $C D H 1$ were identified, as well as a decrease in the mRNA and protein expression levels of SNAII and SNAI2. Therefore, the current results suggested that E7 not only suppressed the expression of $\mathrm{CDH} 1$ via the methylation of its promoter, but also regulated the expression of SNAII, a negative regulator of $C D H 1$ involved in EMT and associated with metastasis (27,55-57). These observations are also concordant with the mechanism of action reported for other oncogenic viruses, where the X protein of HBV (HBx), core protein of $\mathrm{HCV}$ and latent membrane protein 1 (LMP1) of EBV promote EMT and metastasis by inducing the expression SNAII and suppressing CDHI expression (64-67).

Following silencing GAPDH with siRNA, SNAII expression was partially suppressed in HeLa cells at the protein level, but not at mRNA level. This was consistent with a previous study that demonstrated that the interaction of GAPDH with Spl resulted in increased expression of Snai1, which promoted the proliferation and metastasis of cancer cells, and that suppression of $G A P D H$ with shRNA resulted in a significant decrease of Snail in the HCT116 and LoVo cell lines (68). This suggested that GAPDH may serve a role in the metastasis of cervical adenocarcinoma (HeLa) by affecting EMT through the upregulation of Snail expression mediated by Sp1, similar to its role reported in colon cancer (68), but further studies are required to verify this.

It is currently unknown how HPV may activate the expression of SNAII; however, it has been reported that in other cancer types associated with virus, HBx, core and LMPI proteins increased SNAII expression through the activation of the PI3K/Akt and MAPK pathways by transforming growth factor- $\beta$ (TGF- $\beta$ ) action $(64,69-72)$, which is in agreement with a previous study by Peinado et al (73) suggesting that TGF- $\beta$ induces SNAII transcription through MAPK and PI3K.

In the present study, the signaling pathways involved in regulating SNAII expression were not determined; however, previous studies have reported that HR-HPV infection activates the PI3K/Akt/mTOR pathway (74), E7 from HPV upregulates Akt activity though the pRB protein (75) and TGF- $\beta$ stimulates EMT and tumor invasion in SiHa cells (76).

In summary, the results of the present demonstrated that HR-HPV E7 may regulate the expression of $\mathrm{CDH} 1$ by two different pathways, in which Snail is involved. The first pathway involves hypermethylation of the $C D H 1$ promoter region and the expression of Snail, as observed in the HeLa cell line. The second pathway involves hypomethylation of the $C D H 1$ promoter region with expression of Snail as observed in SiHa cell line, suggesting that $C D H 1$ and SNAII may be considered as biomarkers of metastasis in uterine cervical cancer. Therefore, based on the present results and previous evidence that E7 interacts with Dnmt1 and HDAC1 (15-17), it would be beneficial to determine if E7 from HR-HPV may interact with Snail to form a co-repressor complex with either Dnmt1 or HDAC1 in the CDH1 promoter (Fig. 6B and C), which may explain the suppression of $\mathrm{CDH} 1$ expression during the EMT process.

\section{Acknowledgements}

This study is part of the doctoral dissertation project of Pedro Rosendo Chalma, a Doctoral student from Programa de Doctorado en Ciencias Biomédicas (PDCB), Instituto de Investigaciones Biomédicas, Universidad Nacional Autónoma de México (UNAM) and received a fellowship from Consejo Nacional de Ciencia y Tecnología (CONACyT; grant no. 203376). The present study was supported by CONACyT (grant no. 253804 to AG-C) and MINECO (grant no. SAF2013-44739-R to AC). The authors would like to thank Ms. Miriam C. Guido Jiménez (UNAM) and Ms. Raquél López Paniagua (INCan) for their technical support, Dr Erick de la Cruz Hernández (Juarez Autonomous University of Tabasco) and Dr Patricio Gariglio (CINVESTAV-IPN) for providing the cell lines and Dr Alfonso Dueñas Gonzalez (INCan-UNAM) for providing the oligonucleotides for $\mathrm{CDH}$ used in the MSP-Protocol.

\section{Funding}

The present study received additional support of the Fundación Miguel Alemán, A.C. to AGC. PRC received a fellowship from Programa de Movilidad Internacional de Estudiantes de la Coordinación de Estudios de Posgrado (CEP-UNAM) during his doctoral stay at the Universidad Autónoma de Madrid (UAM).

\section{Availability of data and materials}

The datasets used and analyzed during the current study are available from the corresponding author on reasonable request.

\section{Authors' contributions}

PRC performed all experiments, interpreted the data and wrote the manuscript. VAV, GDBO and CCPM performed western blot analysis and interpreted the data. AC and AGC conceived and designed the study, interpreted the data and 
edited the manuscript. All authors have read and approved the final manuscript.

\section{Ethics approval and consent to participate}

Not applicable.

\section{Patient consent for publication}

Not applicable.

\section{Competing interests}

The authors declare that they have no competing interests.

\section{References}

1. Ferlay J, Soerjomataram I, Dikshit R, Eser S, Mathers C, Rebelo M, Parkin DM, Forman D and Bray F: Cancer incidence and mortality worldwide: Sources, methods and major patterns in GLOBOCAN 2012. Int J Cancer 136: E359-E386, 2015.

2. Parkin DM, Bray F, Ferlay J and Pisani P: Global cancer statistics, 2002. CA Cancer J Clin 55: 74-108, 2005.

3. zur Hausen H: Papillomaviruses in the causation of human cancers-a brief historical account. Virology 384: 260-265, 2009.

4. Bansal A, Singh MP and Rai B: Human papillomavirus-associated cancers: A growing global problem. Int J Appl Basic Med Res 6: 84-89, 2016.

5. Hanahan D and Weinberg RA: Hallmarks of cancer: The next generation. Cell 144: 646-674, 2011.

6. Doorbar J: Latent papillomavirus infections and their regulation. Curr Opin Virol 3: 416-421, 2013.

7. Schiffman M, Doorbar J, Wentzensen N, de Sanjosé S, Fakhry C, Monk BJ, Stanley MA and Franceschi S: Carcinogenic human papillomavirus infection. Nat Rev Dis Primers 2: 16086, 2016.

8. Durst M, Kleinheinz A, Hotz M and Gissmann L: The physical state of human papillomavirus type 16 DNA in benign and malignant genital tumours. J Gen Virol 66: 1515-1522, 1985.

9. Lehn H, Villa LL, Marziona F, Hilgarth M, Hillemans HG and Sauer G: Physical state and biological activity of human papillomavirus genomes in precancerous lesions of the female genital tract. J Gen Virol 69: 187-196, 1988.

10. Badal S, Badal V, Calleja-Macias IE, Kalantari M, Chuang LS, $\mathrm{Li} \mathrm{BF}$ and Bernard $\mathrm{HU}$ : The human papillomavirus- 18 genome is efficiently targeted by cellular DNA methylation. Virology 324 : 483-492, 2004.

11. Fernandez AF, Rosales C, Lopez-Nieva P, Graña O, Ballestar E, Ropero S, Espada J, Melo SA, Lujambio A, Fraga MF, et al: The dynamic DNA methylomes of double-stranded DNA viruses associated with human cancer. Genome Res 19: 438-451, 2009.

12. Kalantari M, Lee D, Calleja-Macias IE, Lambert PF and Bernard HU: Effects of cellular differentiation, chromosomal integration and 5-aza-2'-deoxycytidine treatment on human papillomavirus-16 DNA methylation in cultured cell lines. Virology 374: 292-303, 2008.

13. Boyer SN, Wazer DE and Band V: E7 protein of human papilloma virus-16 induces degradation of retinoblastoma protein through the ubiquitin-proteasome pathway. Cancer Res 56: 4620-4624, 1996.

14. Munger K, Phelps WC, Bubb V, Howley PM and Schlegel R: The E6 and E7 genes of the human papillomavirus type 16 together are necessary and sufficient for transformation of primary human keratinocytes. J Virol 63: 4417-4421, 1989.

15. Brehm A, Nielsen SJ, Miska EA, McCance DJ, Reid JL, Bannister AJ and Kouzarides T: The E7 oncoprotein associates with $\mathrm{Mi} 2$ and histone deacetylase activity to promote cell growth. EMBO J 18: 2449-2458, 1999.

16. Burgers WA, Blanchon L, Pradhan S, de Launoit Y, Kouzarides T and Fuks F: Viral oncoproteins target the DNA methyltransferases. Oncogene 26: 1650-1655, 2007.

17. Longworth MS and Laimins LA: The binding of histone deacetylases and the integrity of zinc finger-like motifs of the E7 protein are essential for the life cycle of human papillomavirus type 31 . J Virol 78: 3533-3541, 2004.
18. Zhang Y, LeRoy G, Seelig HP, Lane WS and Reinberg D: The dermatomyositis-specific autoantigen $\mathrm{Mi} 2$ is a component of a complex containing histone deacetylase and nucleosome remodeling activities. Cell 95: 279-289, 1998.

19. Li H, Ou X, Xiong J and Wang T: HPV16E7 mediates HADC chromatin repression and downregulation of MHC class I genes in HPV16 tumorigenic cells through interaction with an MHC class I promoter. Biochem Biophys Res Commun 349: 1315-1321, 2006.

20. Georgopoulos NT, Proffitt JL and Blair GE: Transcriptional regulation of the major histocompatibility complex (MHC) class I heavy chain, TAP1 and LMP2 genes by the human papillomavirus (HPV) type 6b, 16 and 18 E7 oncoproteins. Oncogene 19: 4930-4935, 2000.

21. Milutin Gasperov N, Sabol I, Planinić P, Grubišić G, Fistonić I, Ćorušić A and Grce M: Methylated host cell gene promoters and human papillomavirus type 16 and 18 predicting cervical lesions and cancer. PLoS One 10: e0129452, 2015.

22. Liu J, Lian Z, Han S, Waye MM, Wang H, Wu MC, Wu K, Ding J, Arbuthnot P, Kew M, et al: Downregulation of E-cadherin by hepatitis B virus $X$ antigen in hepatocellullar carcinoma. Oncogene 25: 1008-1017, 2006.

23. McLaughlin-Drubin ME and Munger K: Viruses associated with human cancer. Biochim Biophys Acta 1782: 127-150, 2008.

24. Tsai CN, Tsai CL, Tse KP, Chang HY and Chang YS: The Epstein-Barr virus oncogene product, latent membrane protein 1 , induces the downregulation of E-cadherin gene expression via activation of DNA methyltransferases. Proc Natl Acad Sci USA 99: 10084-10089, 2002.

25. Caberg JH, Hubert PM, Begon DY, Herfs MF, Roncarati PJ, Boniver JJ and Delvenne PO: Silencing of E7 oncogene restores functional E-cadherin expression in human papillomavirus 16-transformed keratinocytes. Carcinogenesis 29: 1441-1447, 2008.

26. Laurson J, Khan S, Chung R, Cross K and Raj K: Epigenetic repression of E-cadherin by human papillomavirus $16 \mathrm{E} 7$ protein. Carcinogenesis 31: 918-926, 2010.

27. Cano A, Perez-Moreno MA, Rodrigo I, Locascio A, Blanco MJ, del Barrio MG, Portillo F and Nieto MA: The transcription factor snail controls epithelial-mesenchymal transitions by repressing E-cadherin expression. Nat Cell Biol 2: 76-83, 2000.

28. Pattillo RA, Hussa RO, Story MT, Ruckert AC, Shalaby MR and Mattingly RF: Tumor antigen and human chorionic gonadotropin in CaSki cells: A new epidermoid cervical cancer cell line. Science 196: 1456-1458, 1977.

29. Friedl F, Kimura I, Osato T and Ito Y: Studies on a new human cell line (SiHa) derived from carcinoma of uterus. I. Its establishment and morphology. Proc Soc Exp Biol Med 135: 543-545, 1970.

30. Diao MK, Liu CY, Liu HW, Li JT, Li F, Mehryar MM, Wang YJ, Zhan SB, Zhou YB, Zhong RG and Zeng Y: Integrated HPV genomes tend to integrate in gene desert areas in the CaSki, HeLa, and SiHa cervical cancer cell lines. Life Sci 127: 46-52, 2015.

31. Yee C, Krishnan-Hewlett I, Baker CC, Schlegel R and Howley PM: Presence and expression of human papillomavirus sequences in human cervical carcinoma cell lines. Am J Pathol 119: 361-366, 1985.

32. Schneider-Gädicke A and Schwarz E: Different human cervical carcinoma cell lines show similar transcription patterns of human papillomavirus type 18 early genes. EMBO J 5: 2285-2292, 1986.

33. Pater MM and Pater A: Human papillomavirus types 16 and 18 sequences in carcinoma cell lines of the cervix. Virology 145: 313-318, 1985.

34. Pater MM and Pater A: Expression of human papillomavirus types 16 and 18 DNA sequences in cervical carcinoma cell lines. J Med Virol 26: 185-195, 1988.

35. Spence RP, Murray A, Banks L, Kelland LR and Crawford L: Analysis of human papillomavirus sequences in cell lines recently derived from cervical cancers. Cancer Res 48: 324-328, 1988.

36. Meissner JD: Nucleotide sequences and further characterization of human papillomavirus DNA present in the CaSki, SiHa and HeLa cervical carcinoma cell lines. J Gen Virol 80: 1725-1733, 1999.

37. De la Cruz-Hernandez E, Garcia-Carranca A, Mohar-Betancourt A, Dueñas-González A, Contreras-Paredes A, Pérez-Cardenas E, Herrera-Goepfert R and Lizano-Soberón M: Differential splicing of E6 within human papillomavirus type 18 variants and functional consequences. J Gen Virol 86: 2459-2468, 2005. 
38. Vazquez-Vega S, Sanchez-Suarez LP, Andrade-Cruz R, Castellanos-Juarez E, Contreras-Paredes A, Lizano-Soberon M, Garcia-Carranca A and Benitez Bribiesca L: Regulation of p14ARF expression by HPV-18 E6 variants. J Med Virol 85: 1215-1221, 2013.

39. Vazquez-Vega S, Sanchez-Suarez LP, Contreras-Paredes A, Castellanos-Juárez E, Peñarroja-Flores R, Lizano-Soberón M Andrade-Cruz R, García-Carrancá A and Benítez-Bribiesca L: Nuclear co-expression of p14ARF and p16INK4A in uterine cervical cancer-derived cell lines containing HPV. Cancer Biomark 8: 341-350, 2010-2011.

40. Gutierrez J, Garcia-Villa E, Ocadiz-Delgado R, Cortés-Malagón EM, Vázquez J, Roman-Rosales A, Alvarez-Rios E, Celik H, Romano MC, Üren A, et al: Human papillomavirus type $16 \mathrm{E} 7$ oncoprotein upregulates the retinoic acid receptor-beta expression in cervical cancer cell lines and K14E7 transgenic mice. Mol Cell Biochem 408: 261-272, 2015.

41. Momparler RL: Epigenetic therapy of cancer with 5-aza-2'-deoxycytidine (decitabine). Semin Oncol 32: 443-451, 2005.

42. Vigushin DM, Ali S, Pace PE, Mirsaidi N, Ito K, Adcock I and Coombes RC: Trichostatin A is a histone deacetylase inhibitor with potent antitumor activity against breast cancer in vivo. Clin Cancer Res 7: 971-976, 2001.

43. Jiang M and Milner J: Selective silencing of viral gene expression in HPV-positive human cervical carcinoma cells treated with siRNA, a primer of RNA interference. Oncogene 21: 6041-6048, 2002.

44. Lea JS, Sunaga N, Sato M, Kalahasti G, Miller DS, Minna JD and Muller CY: Silencing of HPV 18 oncoproteins with RNA interference causes growth inhibition of cervical cancer cells. Reprod Sci 14: 20-28, 2007.

45. Sledz CA, Holko M, de Veer MJ, Silverman RH and Williams BR Activation of the interferon system by short-interfering RNAs Nat Cell Biol 5: 834-839, 2003.

46. Makpol S, Zainuddin A and Chua KH: GAPDH expression as a measurement of transfection efficiency for p16 INK4a gene silencing (siRNA) in senescent human diploid fibroblasts. Am J Mol Biol 2: 390-397, 2012.

47. Han H: RNA interference to knock down gene expression. Methods Mol Biol 1706: 293-302, 2018

48. Borawski J, Lindeman A, Buxton F, Labow M and Gaither LA: Optimization procedure for small interfering RNA transfection in a 384-well format. J Biomol Screen 12: 546-559, 2007.

49. Peter Hahn JD, Wolfgang Bielke and Jie Kang: Patent: EP2240582 B1-Positive controls for expression modulating experiments. European Patent Office, October 23, 2013.

50. Cheng A, Magdaleno S and Vlassov AV: Optimization of transfection conditions and analysis of siRNA potency using real-time PCR. Methods Mol Biol 764: 199-213, 2011.

51. Badal V, Chuang LS, Tan EH, Badal S, Villa LL, Wheeler CM, $\mathrm{Li} \mathrm{BF}$ and Bernard HU: $\mathrm{CpG}$ methylation of human papillomavirus type 16 DNA in cervical cancer cell lines and in clinical specimens: Genomic hypomethylation correlates with carcinogenic progression. J Virol 77: 6227-6234, 2003.

52. Kalantari M, Calleja-Macias IE, Tewari D, Hagmar B, Lie K, Barrera-Saldana HA, Wiley DJ and Bernard HU: Conserved methylation patterns of human papillomavirus type 16 DNA in asymptomatic infection and cervical neoplasia. J Virol 78 12762-12772, 2004

53. Hoffmann I, Hilger M and Mueller O: Homo sapiens promoter of E-cadherin from HEK293 cells. Max-Planck-Institut fue Molekulare Physiologie, Dortmund, 2006.

54. Livak KJ and Schmittgen TD: Analysis of relative gene expression data using real-time quantitative PCR and the 2(-Delta Delta C(T)) method. Methods 25: 402-408, 2001

55. Peinado $\mathrm{H}$, Portillo $\mathrm{F}$ and Cano A: Transcriptional regulation of cadherins during development and carcinogenesis. Int J Dev Biol 48: 365-375, 2004.

56. Moreno-Bueno G, Cubillo E, Sarrio D, Peinado H, Rodríguez-Pinilla SM, Villa S, Bolós V, Jordá M, Fabra A, Portillo F, et al: Genetic profiling of epithelial cells expressing E-cadherin repressors reveals a distinct role for Snail, Slug, and E47 factors in epithelial-mesenchymal transition. Cancer Res 66 9543-9556, 2006

57. Peinado H, Olmeda D and Cano A: Snail, Zeb and bHLH factors in tumour progression: An alliance against the epithelial phenotype? Nat Rev Cancer 7: 415-428, 2007.
58. Cameron EE, Bachman KE, Myöhänen S, Herman JG and Baylin SB: Synergy of demethylation and histone deacetylase inhibition in the re-expression of genes silenced in cancer. Nat Genet 21: 103-107, 1999.

59. Ou JN, Torrisani J, Unterberger A, Provençal N, Shikimi K, Karimi M, Ekström TJ and Szyf M: Histone deacetylase inhibitor Trichostatin A induces global and gene-specific DNA demethylation in human cancer cell lines. Biochem Pharmacol 73 $1297-1307,2007$

60. Meng F, Sun G, Zhong M, Yu Y and Brewer MA: Anticancer efficacy of cisplatin and trichostatin A or 5-aza-2'-deoxycytidine on ovarian cancer. Br J Cancer 108: 579-586, 2013.

61. Liu YN, Lee WW, Wang CY, Chao TH, Chen Y and Chen JH: Regulatory mechanisms controlling human E-cadherin gene expression. Oncogene 24: 8277-8290, 2005.

62. Chen Y, Wang K, Qian CN and Leach R: DNA methylation is associated with transcription of Snail and Slug genes. Biochem Biophys Res Commun 430: 1083-1090, 2013.

63. Savagner P, Kusewitt DF, Carver EA, Magnino F, Choi C, Gridley T and Hudson LG: Developmental transcription factor slug is required for effective re-epithelialization by adult keratinocytes. J Cell Physiol 202: 858-866, 2005.

64. Arzumanyan A, Friedman T, Kotei E, Ng IO, Lian Z and Feitelson MA: Epigenetic repression of E-cadherin expression by hepatitis B virus x antigen in liver cancer. Oncogene 31: 563-572, 2012.

65. Horikawa T, Yoshizaki T, Kondo S, Furukawa M, Kaizaki Y and Pagano JS: Epstein-Barr Virus latent membrane protein 1 induces Snail and epithelial-mesenchymal transition in metastatic nasopharyngeal carcinoma. Br J Cancer 104: 1160-1167, 2011.

66. Liu H, Xu L, He H, Zhu Y, Liu J, Wang S, Chen L, Wu Q, Xu J and $\mathrm{Gu} \mathrm{J}$ : Hepatitis $\mathrm{B}$ virus $\mathrm{X}$ protein promotes hepatoma cell invasion and metastasis by stabilizing Snail protein. Cancer Sci 103: 2072-2081, 2012

67. Nie D, Shan X, Nie L, Duan Y, Chen Z, Yang Y, Li Z, Tian L, Gao Q, Shan Y and Tang N: Hepatitis C virus core protein interacts with Snail and histone deacetylases to promote the metastasis of hepatocellular carcinoma. Oncogene 35: 3626-3635, 2016.

68. Liu K, Tang Z, Huang A, Chen P, Liu P, Yang J, Lu W, Liao J, Sun Y, Wen S, et al: Glyceraldehyde-3-phosphate dehydrogenase promotes cancer growth and metastasis through upregulation of SNAIL expression. Int J Oncol 50: 252-262, 2017.

69. Liu Y, Xu Y, Ma H, Wang B, Xu L, Zhang H, Song X, Gao L, Liang X and Ma C: Hepatitis B virus X protein amplifies TGF- $\beta$ promotion on HCC motility through down-regulating PPM1a. Oncotarget 7: 33125-33135, 2016.

70. Park GB, Kim D, Kim YS, Kim S, Lee HK, Yang JW and Hur DY: The Epstein-Barr virus causes epithelial-mesenchymal transition in human corneal epithelial cells via Syk/src and Akt/Erk signaling pathways. Invest Ophthalmol Vis Sci 55: 1770-1779, 2014.

71. Sides MD, Klingsberg RC, Shan B, Gordon KA, Nguyen HT, Lin Z, Takahashi T, Flemington EK and Lasky JA: The Epstein-Barr virus latent membrane protein 1 and transforming growth factor- $\beta 1$ synergistically induce epithelial--mesenchymal transition in lung epithelial cells. Am J Respir Cell Mol Biol 44: 852-862, 2011.

72. Taniguchi H, Kato N, Otsuka M, Goto T, Yoshida H, Shiratori Y and Omata M: Hepatitis C virus core protein upregulates transforming growth factor-beta 1 transcription. J Med Virol 72: 52-59, 2004

73. Peinado H, Quintanilla M and Cano A: Transforming growth factor beta-1 induces snail transcription factor in epithelial cell lines: Mechanisms for epithelial mesenchymal transitions. J Biol Chem 278: 21113-21123, 2003.

74. Surviladze Z, Sterk RT, DeHaro SA and Ozbun MA: Cellular entry of human papillomavirus type 16 involves activation of the phosphatidylinositol 3-kinase/Akt/mTOR pathway and inhibition of autophagy. J Virol 87: 2508-2517, 2013.

75. Menges CW, Baglia LA, Lapoint R and McCance DJ: Human papillomavirus type 16 E7 up-regulates AKT activity through the retinoblastoma protein. Cancer Res 66: 5555-5559, 2006.

76. Yi JY, Hur KC, Lee E, Jin YJ, Arteaga CL and Son YS: TGFbeta1-mediated epithelial to mesenchymal transition is accompanied by invasion in the SiHa cell line. Eur J Cell Biol 81: 457-468, 2002. 